\title{
Multiple Air Quality Monitoring Evidence of the Impacts of Large-scale Social Restrictions during the COVID-19 Pandemic in Jakarta, Indonesia
}

Special Issue:

Special Issue on COVID-19 Aerosol Drivers, Impacts and Mitigation (XVI)

\section{OPEN ACCESS}

Received: November 24, 2020

Revised: April 13, 2021

Accepted: April 18, 2021

${ }^{*}$ Corresponding Author:

\section{Publisher:}

Taiwan Association for Aerosol Research

ISSN: $1680-8584$ print

ISSN: 2071-1409 online

\section{Copyright: The Author(s).} This is an open access article distributed under the terms of the Creative Commons Attribution License (CC BY 4.0), which permits unrestricted use, distribution, and reproduction in any medium, provided the original author and source are cited.

\section{Muhayatun Santoso ${ }^{1 *}$, Philip K. Hopke ${ }^{2}$, Didin Agustian Permadi ${ }^{3}$, Endah Damastuti ${ }^{1}$, Diah Dwiana Lestiani ${ }^{1}$, Syukria Kurniawati ${ }^{1}$, Desie Khoerotunnisya ${ }^{4}$, Suradi Karto Sukir ${ }^{5}$}

\author{
${ }^{1}$ Center for Applied Nuclear Science and Technology, National Nuclear Energy Agency (BATAN), \\ Bandung, Indonesia \\ ${ }^{2}$ University of Rochester School of Medicine and Dentistry, Rochester, NY 14642, USA \\ ${ }^{3}$ Institut Teknologi Nasional Bandung, (ITENAS), Indonesia \\ ${ }^{4}$ The Environmental Protection Agency of Jakarta Province, Kuningan, South Jakarta, Indonesia \\ ${ }^{5}$ Agency for Meteorology, Climatology, and Geophysics of Indonesia (BMKG), Jakarta, Indonesia
}

\section{ABSTRACT}

Air pollution is a top contributor to global mortality. Air quality issues abound in developing Asian countries, but during COVID-19 lockdowns, urban air quality improved due to the reduction in public mobility and fuel consumption. In Indonesia, the Large-Scale Social Restriction (LSSR) program was implemented to prevent the wider spread of COVID-19, especially in large urban areas. It was not a total lockdown program but had the purpose of reducing urban public mobility. This study investigated the effects of social restrictions on air quality in Jakarta, Indonesia. Data were obtained from our long-term monitoring of fine $\left(\mathrm{PM}_{2.5}\right)$ and coarse particulate matter (PM 2.5-10) and compositions collected at a site in South Jakarta. Other data were obtained from the environmental protection agency's (EPA's) air quality monitoring station in Central Jakarta including $\mathrm{PM}_{10}, \mathrm{PM}_{2.5}, \mathrm{SO}_{2}, \mathrm{NO}_{2}, \mathrm{CO}$, and $\mathrm{O}_{3}$. The aerosol optical depth (AOD) in Jakarta measured by a sun photometer and satellite data were used to assess the spatial distribution of AOD across Jakarta. During the first LSSR implementation period from 15 March to 30 May 2020, there were decreased average $\mathrm{SO}_{2}, \mathrm{CO}, \mathrm{NO}, \mathrm{NO}_{2}$, and $\mathrm{NO}_{x}$ concentrations of 40 to $60 \%$ compared to the same period in 2019. However, $\mathrm{O}_{3}$ increased by $33 \%$ likely due to reduction in $\mathrm{NO}_{x}$ emissions. $\mathrm{The} \mathrm{PM}_{2.5}$ decline reached $\sim 40 \%$, but a similar decline was not observed for $\mathrm{PM}_{10}$. Elemental and black carbon concentration data showed reductions that ranged from $30 \%$ to more than $50 \%$. Consistent with the PM observations, both ground and satellite based AOD showed reductions in the aerosol column burden over the city. The ground based AOD values showed moderate correlations with $\mathrm{PM}_{2.5}$. The results confirmed that significant reduction in public mobility was highly associated with the improvement of local air quality which useful to derive future control strategies.

Keywords: $\mathrm{PM}_{2.5}, \mathrm{PM}_{10}$, chemical composition, $\mathrm{BC}, \mathrm{AOD}$

\section{INTRODUCTION}

Air pollution has become an important global problem that requires serious attention because of its impacts on human health and environmental quality (Brauer et al., 2016). The deterioration of ambient air quality, especially in big cities needs major improvements. The Global Burden of Disease Project (Murray et al., 2020) reported that air pollution was globally responsible for more than 7.5 million deaths. Other studies showed that fine particulate pollution $\left(\mathrm{PM}_{2.5}\right)$ was highly correlated with population mortality with morbidity (U.S. EPA, 2019; Murray et al., 2020). Long-term exposures to high $\mathrm{PM}_{2.5}$ concentration lead to various respiratory diseases such as 
respiratory infections, asthma, chronic obstructive pulmonary disease (COPD) even lung cancer, since $\mathrm{PM}_{2.5}$ contains various toxic substances and infectious agents that are able to penetrate into our lungs (Burnett et al., 2018; McGuinn et al., 2019; Alemayehu et al., 2020).

Other pollutants including $\mathrm{SO}_{2}, \mathrm{NO}_{2}, \mathrm{CO}$ and $\mathrm{O}_{3}$ also affect human health and ecosystems (Rahman et al., 2019). $\mathrm{SO}_{2}$ and $\mathrm{NO}_{2}$ exposures in high concentrations will damage human health by facilitating respiratory tract infections or exacerbating respiratory illnesses such as asthma, COPD, etc. $\mathrm{SO}_{2}$ and $\mathrm{NO}_{2}$ can combine with rainwater creating acid rain that is hazardous for animals and plants (WHO, 2005, Chen et al., 2007; Rahman et al., 2019). Breathing high concentrations of $\mathrm{O}_{3}$ can reduce the lung function and damage lung tissue. $\mathrm{O}_{3}$ can also trigger a variety of responses such as eye irritation, throat irritation, coughing, and chest pain. The primary sources of emissions of $\mathrm{SO}_{2}$ and $\mathrm{NO}_{2}$ are anthropogenic activities involving the combination of burning fossil fuels, biomass, and the resulting emissions from vehicles and the power plants (Brunekreef and Holgate, 2002). Breathing elevated concentrations of $\mathrm{CO}$ can reduce $\mathrm{O}_{2}$ transport in hemoglobin and cause health effects including headaches, chest pain, heart disease, etc. (Sharma et al., 1999) and moreover acute and chronic exposure in enclosed space will increase the risk for development of cardiopulmonary and cardiovascular events, including death (Chen et al., 2007).

In Indonesia, air pollution is one of many serious environmental problems encountered by major cities due to the high population growth, increasing economic activity, intensive transport, and industrial activities.

The capital city of Indonesia, Jakarta, is a megacity with a 2019 population of nearly 10.5 million people. Jakarta is also surrounded by industrial and sub-urban areas that are located within distance of 20-30 km from the center of the city. The city is characterized by a high mobility of transportation that in turn routinely causes traffic jams. High urban $\mathrm{PM}_{2.5}$ pollution has been observed with frequent violations of the Indonesian annual mean national ambient air quality standard of $15 \mu \mathrm{g} \mathrm{m}^{-3}$ (Santoso et al., 2013; Santoso et al., 2020). Twenty-four-hour PM2.5 values at industrial sites ranged from 15 to $42 \mu \mathrm{g} \mathrm{m}^{-3}$, while at residential sites, values ranged from 9 to $36 \mu \mathrm{g} \mathrm{m}^{-3}$ (Santoso et al., 2011). The $\mathrm{PM}_{2.5}$ concentrations measured in Jakarta at an arterial roadside were higher than those measured in the other Indonesian big cities. The mean concentrations of $\mathrm{PM}_{2.5}$ and $\mathrm{PM}_{10}$ were 25.76 and $75.20 \mu \mathrm{g} \mathrm{m}^{-3}$, respectively. Another critical air pollutant that contributed to the dangerous air quality index in Jakarta was surface ozone $\left(\mathrm{O}_{3}\right)$ due to intensive build-up of local precursor emissions (e.g., $\mathrm{NO}_{\mathrm{x}}$ ) and the meteorological conditions favorable to photochemical reactions (Suhadi et al., 2005; Permadi and Kim Oanh, 2008). In Jakarta, the mean of $\mathrm{NO}_{2}$ concentrations using passive samplers showed the weekly average of $20-70 \mu \mathrm{g} \mathrm{m}^{-3}$, while the peak daily concentration was $446 \mu \mathrm{g} \mathrm{m}^{-3}$. Annual average of $\mathrm{NO}_{2}$ in Asian cities typically in the range of 23-74 $\mu \mathrm{g} \mathrm{m}^{-3}$ (WHO, 2005). Jakarta reported weekly average concentrations of $\mathrm{SO}_{2}$ between $4 \mu \mathrm{g} \mathrm{m}^{3}$ and $24 \mu \mathrm{g} \mathrm{m}^{-3}$ (WHO, 2005). This value does not differ significantly from those reported in central Jakarta in 2017. The reported mean $\mathrm{SO}_{2}$ was $22.72 \mu \mathrm{g} \mathrm{m}^{-3}$, while average $\mathrm{NO}_{2}$ was $11.85 \mathrm{~g} \mathrm{~m}^{-3}$ (Rahman and Barus, 2019).

In late 2019, a contagious virus appeared in China that was identified as a novel strain of coronavirus belonging to the same family as acute respiratory syndrome (SARS) and Middle East respiratory syndrome (MERS) (Liu et al., 2020; Zhu et al., 2020). Then, the so-called coronavirus disease 2019 (COVID-19) was declared by the World Health Organization (WHO) as a worldwide pandemic in the mid-March 2020 based on the report of 118,319 cases and 4,292 deaths globally (WHO, 2020). Although this novel virus is close to the coronavirus found in animals, COVID-19 has been confirmed to be transmitted from human-to-human and has drawn significant attention globally (Hsiao et al., 2020; Guo et al., 2020; Shereen et al., 2020). Most of affected countries have been implementing restriction of activity (lockdown) measures with various level of stringency that were reported to require drastic reductions in public mobility and fossil fuel consumption. A global study using various satellite products showed that the air pollution in China, Italy, Spain and USA had declined by up to $30 \%$ while reductions were mobility was up to $90 \%$ (Muhammad et al., 2020). In Asia, many studies were conducted to investigate the impacts of various COVID-19 related measures on air quality in India, China, and Malaysia (Abdullah et al., 2020; Chen et al., 2020; Mahato et al., 2020), but more similar studies are required in other countries including in Indonesia. The results elsewhere showed substantial reductions in air pollutant concentrations (gases and PM) that somehow showed the effectiveness of the lockdown programs in reducing emissions.

The first case of COVID-19 in Indonesia was identified in February 2020. Since then, the virus 
has spread widely across Indonesia and still showing an increasing rate of new cases up to November 2020. Jakarta has become epicentral of the spread of COVID-19 in Indonesia with the highest number of confirmed cases of COVID-19 as well as deaths. On 16 March 2020, the Governor of Jakarta implemented a policy, named as Large-Scale of Social Restriction (LSSR) to prevent a wide spread of COVID-19. This action strictly limited the anthropogenic activities in Jakarta with only limited essential services such as health care, logistics, food supply, and banking being allowed to operate. Therefore, there were fewer vehicles on the roads, many cancelled flights, and restricted construction and industrial activities that led to decreased air pollutant concentrations.

The objective of the current study was to provide the evidence derived from various observation techniques on the impacts of the LSSR implementation on the air quality in Jakarta, Indonesia.

\section{METHODS}

We used three sources of ground-based monitoring data in Jakarta: a) automatic ambient air quality monitoring station (AQMS) for PM and gases, b) PM filter-based measurement (i.e., PM mass, carbonaceous and elemental compositions), and c) Aerosol Optical Depth (AOD) measured by sun-photometer equipment. In addition, we also retrieved Terra Moderate Resolution Imaging Spectroradiometer (MODIS) AOD to visualize the spatial distribution of column aerosol burden over the study area (https://giovanni.gsfc.nasa.gov/giovanni/).

The first of the three sites are shown in Fig. 1 as site (A). This site is located in the central business district (CBD) of Jakarta with a coordinate of 6 $11^{\prime} 40.78^{\prime \prime} S / 106^{\circ} 49^{\prime} 24.92^{\prime \prime E}$. This air quality monitoring site is managed by the Environmental Protection Agency (EPA) of Jakarta Province with regular quality assurance and quality control (QA/QC) to provide continuous monitoring of $\mathrm{PM}_{10}$, $\mathrm{PM}_{2.5}, \mathrm{CO}, \mathrm{SO}_{2}, \mathrm{O}_{3}$ and $\mathrm{NO}_{2}$. Continuous monitoring of PM mass uses the standard Federal Reference Method (FRM) Beta Attenuation (BAM) (Verewa F701-20 for PM10 and Horiba APDA-371 for PM2.5). Standard continuous gas analyzers have been used as follows: $\mathrm{O}_{3}$ (HORIBA APOA-370), CO

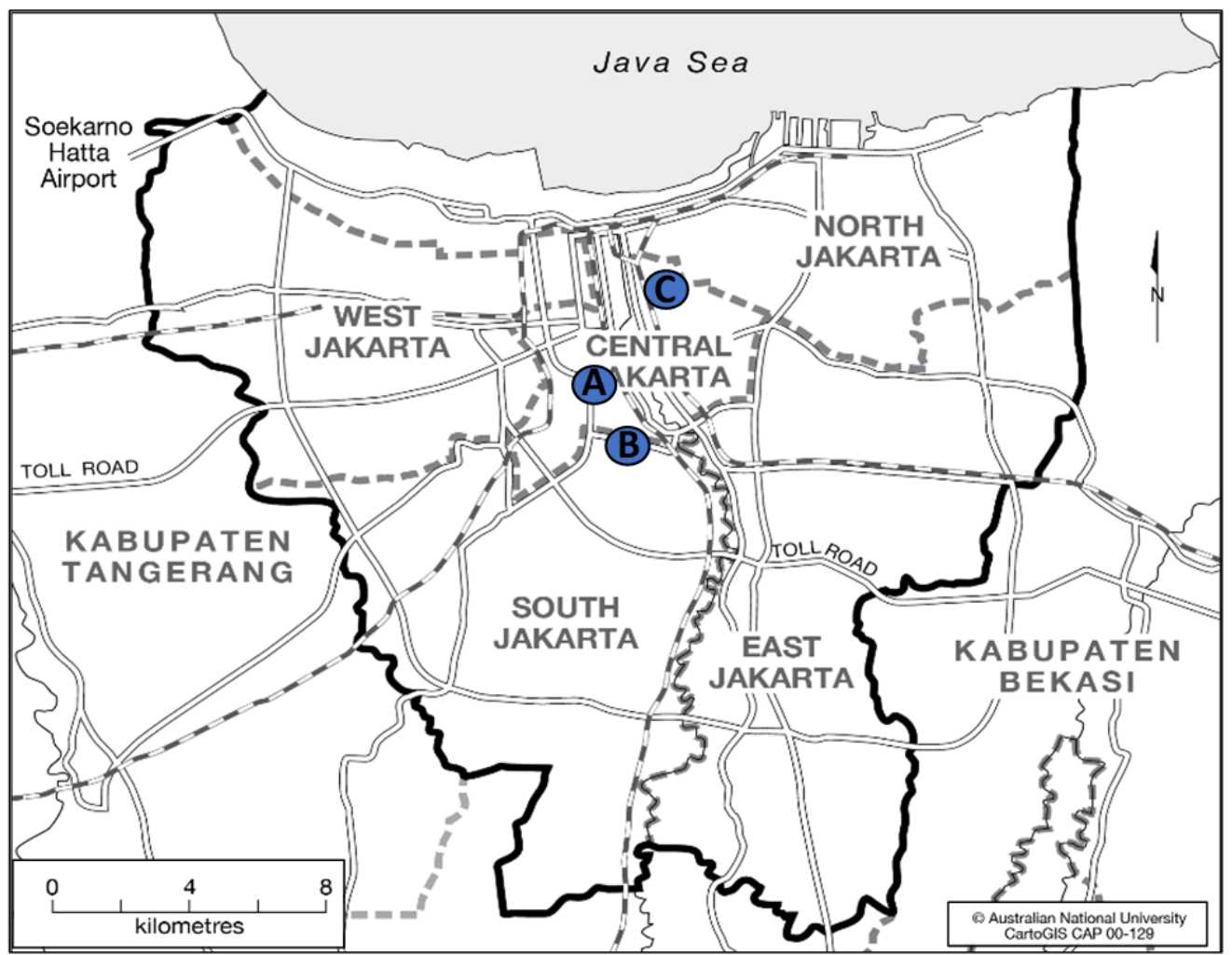

Fig. 1. Locations of sampling sites in Jakarta (source: adapted from Australian National University). 
(HORIBA APMA-370), $\mathrm{SO}_{2}$ (HORIBA APSA-370), and $\mathrm{NO}_{\times}$(HORIBA APNA-370). The data are averaged for every 30 minutes.

We conducted long-term PM monitoring $\left(2^{\text {nd }}\right.$ site) at the provincial EPA office located on Casablanca Street, Central Jakarta $06^{\circ} 13^{\prime} 34.08^{\prime \prime}$, $106^{\circ} 50^{\prime} 04.42^{\prime \prime} E$ ) shown in Fig. 1 as site (B). This site is situated in the center of the city and is surrounded by an arterial road with heavy traffic especially in the morning and in the evening. The dichotomous sampler was located on the fourth-floor roof about $18 \mathrm{~m}$ above ground level. Integrated filter sampling was conducted using a Gent stacked filter unit (SFU) particle sampler capable of collecting particulate matter in $\mathrm{PM}_{2.5-10}$ and $\mathrm{PM}_{2.5}$ size fractions (Hopke et al., 1997). The samples were collected on an $8 \mu \mathrm{m}$ pore nucleopore filter for the coarse fraction sample and on an $0.4 \mu \mathrm{m}$ pore nucleopore filter for the fine fraction sample. The samples were collected from September 2019 until May 2020 for $24 \mathrm{~h}$ at least once per week. The aerosol masses of both $\mathrm{PM}_{2.5-10}$ and $\mathrm{PM}_{2.5}$ fractions were determined by weighing the filters before and after exposure, then divided by the volume of air passing through the filter to obtain the concentration of $\mathrm{PM}_{2.5}$ and $\mathrm{PM}_{2.5-10}\left(\mu \mathrm{g} \mathrm{m}^{-3}\right)$. The $\mathrm{PM}_{10}$ mass concentration was obtained by summing up these two values.

Light absorbing carbon (black carbon, BC) in the samples was determined by reflectance measurement using an EEL model 43D smoke stain reflectometer that measures the reduction in reflected white light (Coulson and Ellison, 1963; Commins and Waller, 1967; Biswas et al., 2003). Secondary standards of known BC concentrations are used to calibrate the reflectometer (Biswas et al., 2003; Begum, et al., 2011). The light reflected or absorbed in the filter sample depends on particle concentration, density, refractive index and size. The sample filter is then placed on a white standard and then measured its reflection value by repeating it three times (Lestiani et al., 2008; Diffusion system manufacture, 2012). The reflectance value obtained from the filter sample is a value that is proportional to the number of $B C$ in the filter using the assumption of an average of particle mass absorption coefficient of $5.7 \mathrm{~m}^{2} \mathrm{~g}^{-1}$ (Seneviratne, 2011).

The collected samples were analyzed for chemical composition using X-ray Fluorescence (XRF). Multielement analyses were performed using an Epsilon 5 ED-XRF (Panalytical, Ltd.) that has 9 secondary targets $\left(\mathrm{Fe}, \mathrm{CaF}_{2}, \mathrm{Ge}, \mathrm{Zr}, \mathrm{CeO}_{2}, \mathrm{Mo}, \mathrm{Ag}\right.$, $\mathrm{Al}$ and one Barkla polarizing target $\left(\mathrm{Al}_{2} \mathrm{O}_{3}\right)$ ). Single element MicroMatter standards were used to develop the calibration parameters, while for method validation, NIST SRM 2783 samples were periodically analyzed. These methods are described in detail in the previous studies (Landsberger and Creatchman (1999); Santoso and Lestiani (2014). XRF analysis of the APM filters determined the concentrations of $\mathrm{Na}, \mathrm{Mg}, \mathrm{Al}, \mathrm{Si}$, $\mathrm{S}, \mathrm{K}, \mathrm{Ca}, \mathrm{Ti}, \mathrm{V}, \mathrm{Cr}, \mathrm{Mn}, \mathrm{Fe}, \mathrm{Co}, \mathrm{Ni}, \mathrm{Cu}, \mathrm{Zn}, \mathrm{Pb}$ and $\mathrm{As}$.

The third location of the monitoring site is shown in Fig. 1 as site (C) and is surrounded by office buildings and human settlements. Measurements of AOD using sun photometer were conducted by the National Bureau of Meteorology, Climatology and Geophysics (BMKG) under the support of The National Aeronautics and Space Administration (NASA), Aerosol Robotic Network (AERONET). This site is part of the largest sun photometer network in the world (Holben et al., 1998). The measurement system is a solar-powered CIMEL Electronique 318A spectral radiometer that measures sun and sky radiances at a number of fixed wavelengths within the visible and near infra-red (VNIR) spectrum.

The stations are situated at a distance, for example, between station $A$ and $B$ of about $3 \mathrm{~km}$ while between station $A$ and $C$ there is a distance of about $4 \mathrm{~km}$. The length span between station $C$ and $B$ is more than $6 \mathrm{~km}$. Therefore, the selected stations represent different city background.

\subsection{Statistical Analyses}

To determine the changes in pollutant concentrations resulting from the reduced anthropogenic activity during the COVID19 lockdown period, several non-parametric tests were performed to compare the data from 4 periods: Pre-LSSR 2020 (January 1-March 15, 2020), LSSR 2020 (March 16, 2020-May 31, 2020), Comparable Pre-LSSR 2019 (January 1-March 15, 2019), and Comparable LSSR 2019 (March 16-May 31, 2019). The distributions of each pollutant were found to not be normal distributions and thus, comparisons among the 4 periods were done using the KruskalWallis ANOVA on ranks (Kruskal and Wallis, 1952). Individual pairwise comparisons were made using the Bonferroni procedure (Bonferroni, 1936). To further confirm these results, the data were also subjected to Mood's Median Test (Mood, 1954). Mood's median test was carried out to examine the hypothesis that the medians of all 4 samples are equal. It does so by counting the 
number of observations in each sample on either side of the grand median over all 4 data subsets. A probability value is calculated based on a chi-square test.

\section{RESULTS AND DISCUSSION}

\subsection{Continuous Ambient Air Quality Data}

Particulate matter $\left(\mathrm{PM}_{10}\right.$ and $\left.\mathrm{PM}_{2.5}\right)$ and gas measurement data $\left(\mathrm{CO}, \mathrm{SO}_{2}, \mathrm{O}_{3}, \mathrm{NO}, \mathrm{NO}_{2}\right)$ were obtained from a continuous air quality monitoring station located in Central Jakarta that is located about $5 \mathrm{~m}$ from a major road. We compared the period average of $\mathrm{PM}_{10}, \mathrm{PM}_{2.5}, \mathrm{SO}_{2}, \mathrm{CO}$, $\mathrm{O}_{3}$, and $\mathrm{NO}_{2}$ concentrations before ( $1^{\text {st }}$ January-1 $15^{\text {th }}$ March, named as Pre-LSSR) and during the LSSR (16 ${ }^{\text {th }}$ March-31 $1^{\text {st }}$ May) for two years: 2019 and 2020. In addition, diel variations for Pre-LSSR and LSSR periods were analyzed for both particulate matter and gases.

The statistical summary for hourly values of each pollutant as well as hourly rainfall in each of the 4 periods is provided in Table 1. The results of the Kruskal-Wallis ANOVA on ranks and Bonferroni procedures for pairwise comparisons are summarized in Table 2. The detailed results of these analyses are presented in the Supplementary Material. There were significant differences among the 4 periods for each measured variable. The entries in the table indicate the statistically significant differences between pairs of periods. A plus $(+)$ sign indicates that the first named period median which was greater than the second named period while a negative (-) sign indicates the opposite direction. A similar analysis was made for the rainfall data for each period.

\subsubsection{Particulate matter}

The distributions of $\mathrm{PM}_{10}$ and $\mathrm{PM}_{2.5}$ derived from hourly data for all 4 periods are presented as box and whisker plots in Fig. 2. The average values of PM 10 for Pre-LSSR 2020 and LSSR 2020 were $41.0 \pm 18.4$ and $49.4 \pm 20.3 \mu \mathrm{g} \mathrm{m}^{-3}$, respectively. The average values of $\mathrm{PM}_{2.5}$ for Pre-LSSR 2020 and LSSR 2020 were $23.8 \pm 16.7$ and $26.5 \pm 15.5 \mu \mathrm{g} \mathrm{m}^{-3}$, respectively. $\mathrm{PM}_{10}$ and $\mathrm{PM}_{2.5}$ were higher in the LSSR 2020 period than in the Pre-LSSR 2020 period. This difference may be the result of much higher total rainfall in the Pre-LSSR 2020 period $(836 \mathrm{~mm})$ than in any of the other 3 periods $(195,290$, and $207 \mathrm{~mm}$, respectively, for the other 3 periods). Period average values of rainfall intensity (in $\mathrm{mm}$ ) for different periods is presented in Fig. S1. Precipitation reduces $\mathrm{PM}_{2.5}$ concentrations at a lower extent than it reduces $\mathrm{PM}_{10}$ concentrations (Blanco-Becerra et al., 2015; Zhou et al., 2020). Comparing the LSSR period in 2019 with the LSSR 2020 period showed that the average $\mathrm{PM}_{2.5}$ values were $45.4 \pm 21.3$ and $26.5 \pm 15.5 \mu \mathrm{g} \mathrm{m}^{-3}$, respectively, while $\mathrm{PM}_{10}$ concentrations were $46.1 \pm 18.8$ and $49.4 \pm 27.3 \mu \mathrm{g} \mathrm{m}^{-3}$, respectively. $\mathrm{PM}_{2.5}$ in 2019 was substantially higher than in 2020. However, $\mathrm{PM}_{10}$ in 2019 was slightly lower than in 2020. This difference could be due to the somewhat higher rainfall intensity in 2019 (Fig. S1), showing that the LSSR in 2020 had a greater effect on $\mathrm{PM}_{2.5}$ than on $\mathrm{PM}_{10}$. Thus, there are other sources of $\mathrm{PM}_{10}$ that were unaffected by the LSSR.

To examine these temporal patterns in more detail, the hour-by-hour data have also been analyzed for differences over these 4 defined periods. Fig. 3 show the hour-by-hour box and whisker plots showing the distributions of $\mathrm{PM}_{2.5}$. The maximum diel average of $\mathrm{PM}_{2.5}$ also showed consistent result with the mean values with lower value during the LSSR period in 2020 (LSSR 2020) as compared to both periods in 2019. However, the Pre-LSSR 2020 value was lower than the LSSR 2020 period due to high rainfall (Fig. S1). For $\mathrm{PM}_{10}$, the maximum diel average value of LSSR 2020 period was higher as compared to all other periods (Fig. S2). Typical diel pattern of $\mathrm{PM}_{10}$ was seen for all periods with higher values during daytime. For $\mathrm{PM}_{2.5}$, higher values were seen at the late night may reflect the lower dispersion characteristics overnight when wind speeds and mixed layer heights would lead to lower dilution of ground level emissions. The higher daytime $\mathrm{PM}_{10}$ concentrations may reflect higher windspeeds to suspend coarse mode particles beginning after sunrise. The concentrations decreased in the afternoon as the mixed layer heights increase.

\subsubsection{Gases $\left(\mathrm{SO}_{2}, \mathrm{CO}, \mathrm{NO}, \mathrm{NO}_{2}, \mathrm{NO}_{x}\right.$, and $\left.\mathrm{O}_{3}\right)$}

Box and whisker plots for the gaseous pollutants are given in Fig. 4. $\mathrm{SO}_{2}, \mathrm{CO}$, and the oxides of nitrogen ( $\mathrm{NO}, \mathrm{NO}_{2}$, and $\mathrm{NO}_{x}$ ) were substantially lower during the LSSR 2020 period compared to the prior months in 2020. The LSSR 2019 period had higher $\mathrm{CO}, \mathrm{SO}_{2}, \mathrm{NO}, \mathrm{NO}_{2}$, and $\mathrm{NO}_{\mathrm{x}}$ than in 
Table 1. Summary of the statistics for each pollutant for each of the 4 analysis periods.

\begin{tabular}{|c|c|c|c|c|c|c|c|c|c|}
\hline & $\begin{array}{l}\mathrm{PM}_{10} \\
\left(\mu \mathrm{g} \mathrm{m}^{-3}\right)\end{array}$ & $\begin{array}{l}\mathrm{PM}_{2.5} \\
\left(\mu \mathrm{g} \mathrm{m}^{-3}\right)\end{array}$ & $\begin{array}{l}\mathrm{SO}_{2} \\
\left(\mu \mathrm{g} \mathrm{m}^{-3}\right)\end{array}$ & $\begin{array}{l}\mathrm{CO} \\
\left(\mu \mathrm{g} \mathrm{m}^{-3}\right)\end{array}$ & $\begin{array}{l}\mathrm{O}_{3} \\
\left(\mu \mathrm{g} \mathrm{m}^{-3}\right)\end{array}$ & $\begin{array}{l}\text { NO } \\
\left(\mu \mathrm{g} \mathrm{m}^{-3}\right)\end{array}$ & $\begin{array}{l}\mathrm{NO}_{2} \\
\left(\mu \mathrm{g} \mathrm{m}^{-3}\right)\end{array}$ & $\begin{array}{l}\mathrm{NO}_{\mathrm{x}} \\
\left(\mu \mathrm{g} \mathrm{m}^{-3}\right)\end{array}$ & $\begin{array}{l}\text { Rain } \\
(\mathrm{mm})\end{array}$ \\
\hline \multicolumn{10}{|l|}{ Pre-LSSR2020 } \\
\hline Count & 1761 & 1155 & 1674 & 1758 & 1754 & 1752 & 1762 & 1760 & 1793 \\
\hline Average & 41.01 & 23.78 & 22.22 & 1.31 & 38.84 & 38.85 & 48.45 & 86.30 & 0.47 \\
\hline Standard deviation & 18.36 & 16.70 & 20.93 & 1.01 & 19.79 & 33.92 & 30.92 & 64.59 & 2.38 \\
\hline Coeff. of variation (\%) & 0.45 & 0.70 & 0.94 & 0.77 & 0.51 & 0.87 & 0.64 & 0.75 & $511 \%$ \\
\hline Minimum & 9.00 & 0.30 & 0.11 & 0.01 & 2.66 & 0.19 & 1.91 & 1.91 & 0 \\
\hline Maximum & 128.00 & 152.15 & 154.24 & 8.18 & 204.48 & 233.79 & 216.38 & 450.16 & 34.95 \\
\hline Range & 119.00 & 151.85 & 154.13 & 8.17 & 201.82 & 233.60 & 214.47 & 448.25 & 34.95 \\
\hline Stnd. skewness & 24.35 & 26.88 & 45.11 & 27.27 & 32.35 & 25.12 & 18.80 & 22.03 & 133.0 \\
\hline Stnd. kurtosis & 22.94 & 43.83 & 98.68 & 31.27 & 57.50 & 20.77 & 11.13 & 15.70 & 609.8 \\
\hline \multicolumn{10}{|l|}{ LSSR2020 } \\
\hline Count & 1847 & 1825 & 1810 & 1763 & 1821 & 1825 & 1824 & 1823 & 1848 \\
\hline Average & 49.39 & 26.54 & 7.88 & 0.53 & 52.57 & 10.46 & 22.69 & 33.85 & 0.11 \\
\hline Standard deviation & 20.21 & 15.54 & 7.17 & 0.44 & 31.31 & 11.25 & 13.66 & 24.41 & 0.891 \\
\hline Coeff. of variation & 0.41 & 0.59 & 0.91 & 0.83 & 0.60 & 1.08 & 0.60 & 0.72 & $844 \%$ \\
\hline Minimum & 11.00 & 0.05 & 0.03 & 0.01 & 14.16 & 0.55 & 1.42 & 2.86 & 0 \\
\hline Maximum & 161.02 & 130.04 & 76.10 & 4.36 & 212.89 & 109.71 & 118.62 & 228.33 & 18.5 \\
\hline Range & 150.02 & 129.99 & 76.07 & 4.35 & 198.73 & 109.16 & 117.20 & 225.47 & 18.5 \\
\hline Stnd. skewness & 19.66 & 24.18 & 45.32 & 43.92 & 28.37 & 55.81 & 32.61 & 42.95 & 251.6 \\
\hline Stnd. kurtosis & 21.40 & 29.79 & 102.82 & 93.01 & 28.47 & 132.14 & 52.92 & 85.38 & 2118.5 \\
\hline \multicolumn{10}{|l|}{ Pre-LSSR2019 } \\
\hline Count & 1760 & 1736 & 1696 & 1723 & 1630 & 1719 & 1562 & 1696 & 1766 \\
\hline Average & 49.44 & 36.25 & 28.05 & 1.75 & 52.36 & 47.60 & 37.73 & 80.26 & 0.16 \\
\hline Standard deviation & 27.27 & 22.79 & 12.34 & 1.05 & 48.35 & 35.52 & 24.36 & 46.69 & 1.00 \\
\hline Coeff. of variation & 0.55 & 0.63 & 0.44 & 0.60 & 0.92 & 0.75 & 0.65 & 0.58 & $612 \%$ \\
\hline Minimum & 2.00 & 0.55 & 5.94 & 0.05 & 4.38 & 0.87 & 0.22 & 4.51 & 0 \\
\hline Maximum & 173.67 & 406.22 & 131.54 & 6.23 & 355.46 & 231.22 & 148.49 & 307.28 & 19.6 \\
\hline Range & 171.67 & 405.67 & 125.60 & 6.18 & 351.08 & 230.35 & 148.27 & 302.77 & 19.6 \\
\hline Stnd. skewness & 19.42 & 58.16 & 43.16 & 18.93 & 31.66 & 24.51 & 15.36 & 13.48 & 193.7 \\
\hline Stnd. kurtosis & 12.12 & 349.19 & 82.22 & 10.78 & 37.14 & 20.72 & 8.80 & 4.34 & 1388.8 \\
\hline \multicolumn{10}{|l|}{ LSSR2019 } \\
\hline Count & 1843 & 1823 & 1811 & 1820 & 1819 & 1817 & 1813 & 1818 & 1848 \\
\hline Average & 46.13 & 45.43 & 13.14 & 1.72 & 39.45 & 38.86 & 43.83 & 83.95 & 0.11 \\
\hline Standard deviation & 18.77 & 21.29 & 8.54 & 0.95 & 34.32 & 29.10 & 20.96 & 36.93 & 0.87 \\
\hline Coeff. of variation & 0.41 & 0.47 & 0.65 & 0.55 & 0.87 & 0.75 & 0.48 & 0.44 & $776 \%$ \\
\hline Minimum & 8.00 & 5.01 & 0.32 & 0.22 & 6.99 & 0.06 & 2.97 & 10.26 & 0 \\
\hline Maximum & 151.54 & 197.80 & 63.30 & 6.36 & 221.54 & 202.42 & 142.72 & 230.74 & 17.9 \\
\hline Range & 143.54 & 192.79 & 62.98 & 6.14 & 214.55 & 202.36 & 139.75 & 220.48 & 17.9 \\
\hline Stnd. skewness & 20.37 & 15.86 & 27.30 & 23.04 & 32.09 & 25.82 & 13.36 & 10.90 & 219.7 \\
\hline Stnd. kurtosis & 28.12 & 21.56 & 26.71 & 17.21 & 31.81 & 24.64 & 9.61 & 1.94 & 1710.5 \\
\hline
\end{tabular}

2020. Thus, there were remarkable reductions of $\mathrm{SO}_{2}, \mathrm{CO}$, and $\mathrm{NO}_{2}$ during the LSSR 2020 as compared to other periods. In Jakarta, some sectors such as transportation and industrial activities experienced a significant decrease since people was encouraged to stay at home due to the virus. Many sources reported that declines in transportation by rail (7\%), sea public transportation (50.7\%), air transportation (82.4\%) and private car (19.3\%). The mobility of the people going to the market and pharmacy fell by $67 \%$. Those going to the mall/café were down by $77 \%$. The decrease in travel wass expected to be higher in parallel with the increases in positive cases of COVID-19 (Caraka et al., 2020). Thus, the emissions of $\mathrm{SO}_{2}, \mathrm{CO}$, and $\mathrm{NO}_{2}$ were also reduced. $\mathrm{NO}_{2}$ showed its lowest value during the LSSR 2020 period. This difference suggests that these species were dominantly affected by traffic emissions. The primary sources of anthropogenic emissions of $\mathrm{SO}_{2}$, 
Table 2. Results of the Kruskal-Wallis ANOVA on Ranks and Bonferroni Procedure for Pairwise Comparisons. ${ }^{a}$

\begin{tabular}{lllllll}
\hline & LSSR2020- & Pre2019- & LSSR2019- & PreLSSR2019- & LSSR2019- & LSSR2019- \\
& PreLSSR2020 & PreLSSR2020 & PreLSSR2020 & LSSR2020 & LSSR2020 & PreLSSR2019 \\
\hline $\mathrm{PM}_{10}$ & + & + & + & - & - & + \\
$\mathrm{PM}_{2.5}$ & + & + & + & + & + & + \\
$\mathrm{SO}_{2}$ & - & + & + & + & + & - \\
$\mathrm{CO}$ & - & + & - & - & + & - \\
$\mathrm{O}_{3}$ & + & + & + & + & + & + \\
$\mathrm{NO}$ & - & - & + & + & + \\
$\mathrm{NO}_{2}$ & - & + & + & + & + \\
$\mathrm{NO}_{x}$ & - & + & + & + & + \\
Rain & - & + & + & + & + \\
\hline
\end{tabular}

Entries are significant at the $95^{\text {th }}$ recent confidence level.
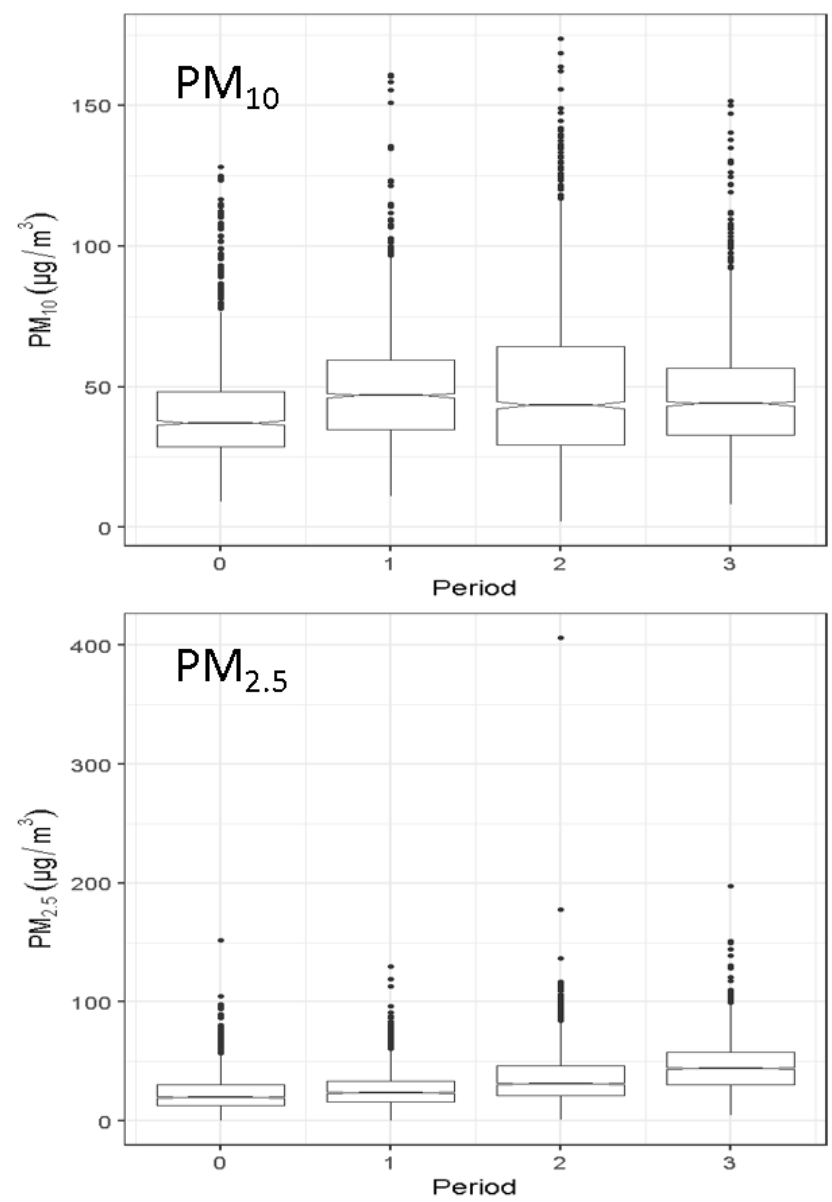

Fig. 2. Box and whisker plots of the distributions of $P M_{10}$ (Top) and $P_{2.5}$ (Bottom) in $\mu \mathrm{g} \mathrm{m}^{-3}$ for the periods: 0-Pre-LSSR 2020, 1-LSSR 2020, 2-Pre-LSSR 2019, 3-LSSR 2019.

$\mathrm{CO}$, and $\mathrm{NO}_{2}$ into the atmosphere are combustion of carbon containing fuels (fossil fuels, coal, wood, etc.) and the resulting emissions from cars, trucks, buses, and power plants (WHO, 2005; Rahman et al., 2019).

Box and whisker plots for the $\mathrm{O}_{3}$ is given in Fig. 5. The average ozone concentration (secondary pollutant) was higher in the LSSR 2020 compared to the Pre-LSSR 2020 and LSSR 2019 periods that can be understood by changes in urban photochemistry. The reduction in primary $\mathrm{NO}_{x}$ emissions led to reduced titration of the $\mathrm{O}_{3}$ and increased the $\mathrm{O}_{3}$ concentration. Thus, the $\mathrm{O}_{3}$ concentrations were highest during the LSSR 2020 period. Meteorological factors also affected 


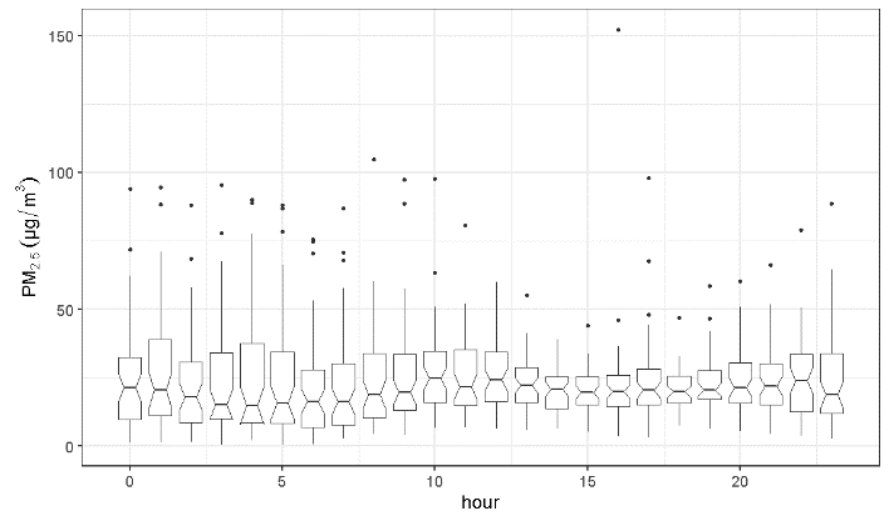

(a)

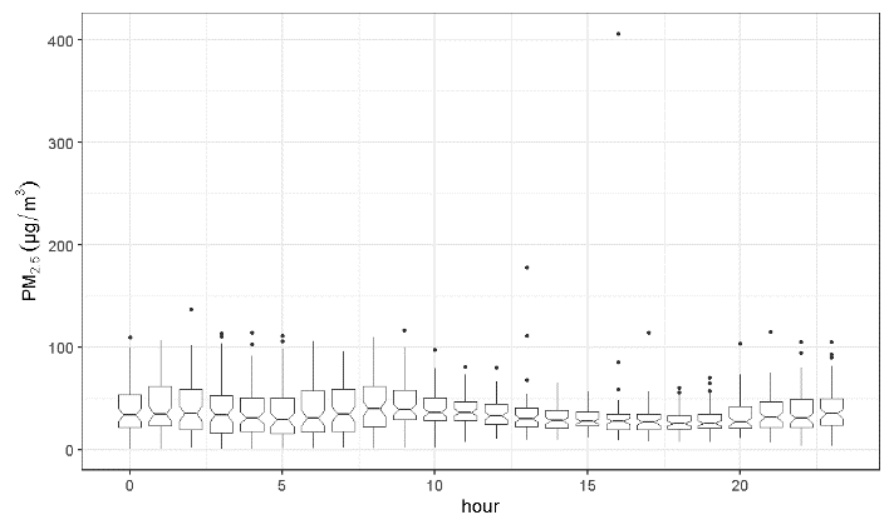

(c)

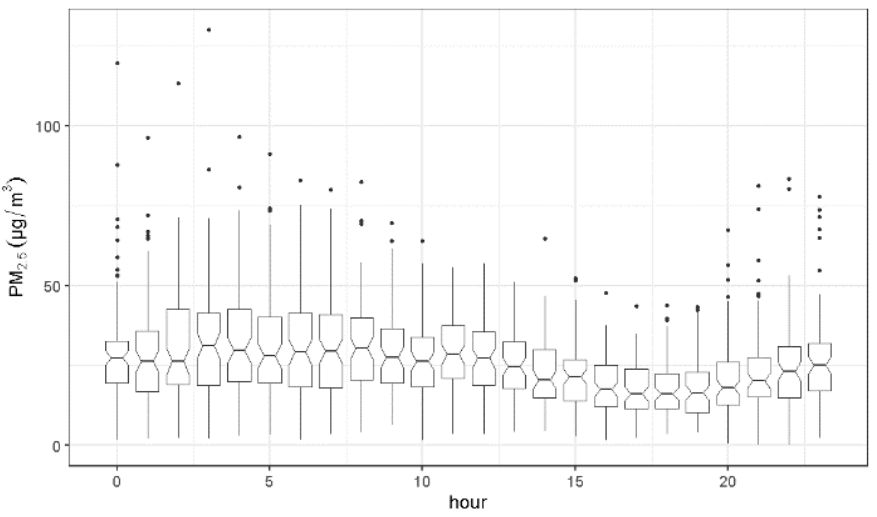

(b)

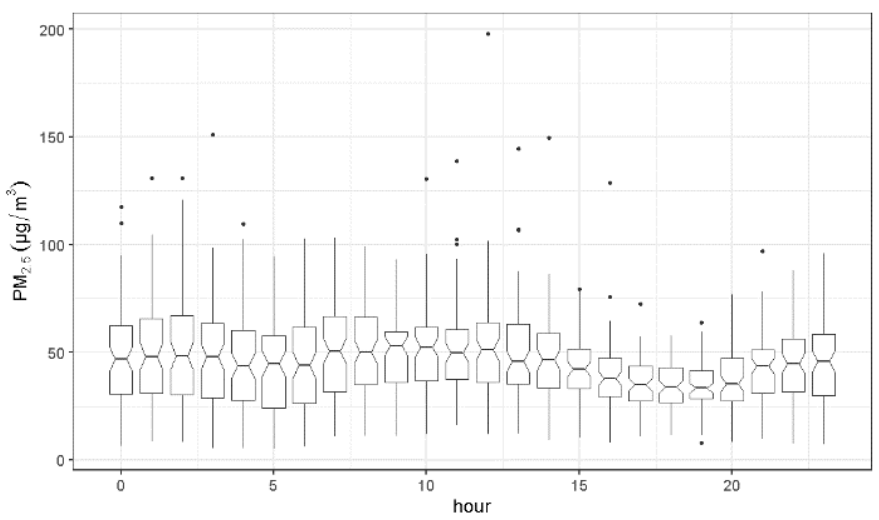

(d)

Fig. 3. Hourly distributions of $\mathrm{PM}_{2.5}$ for each of the 4 study periods; (a) Pre-LSSR 2020, (b) LSSR 2020, (c) Pre-LSSR 2019 and (d) LSSR 2019.

the measured ozone concentrations as well as the VOC emissions from local and regional nontraffic sources. This result is similar to what has been observed in many other locations around the world (e.g., Abdullah et al., 2020; Chen et al., 2020; Mahato et al., 2020; Huang et al., 2021; Qiu et al., 2021). The increased ozone suggests that Jakarta is in a VOC-limited regime for ozone formation (Seinfeld and Pandis, 2016) so that reducing NO emissions led to increased ozone. There are relatively small differences in the monthly average photoperiods ranging from $12.4 \mathrm{~h}$ in January to $11.8 \mathrm{~h}$ in June so that variations in photochemical activity and temperature are much less than in many other locations observing increased ozone concentrations.

We also compared the diel patterns between LSSR 2020 period and corresponding period in 2019 and the results are presented in Fig. 6. Even though the patterns are typical, but the concentrations of $\mathrm{SO}_{2}, \mathrm{CO}$, and NO in 2019 are far higher than those measured during the LSSR 2020 period especially for the maximum diel values. For ozone, the diel average concentrations are in a comparable magnitude for both periods. Non-day time ozone concentrations in LSSR 2020 period are slightly higher than the corresponding period in 2019 may be due to less $\mathrm{NO}_{\mathrm{x}}$ emissions.

Fig. 6 shows the $\mathrm{O}_{3}$ diel patterns with sharp rises beginning at 10:00 in both LSSR periods, but higher values in 2020 . The NO during the morning rush hour was significantly reduced from the comparable time of day in the other 3 periods (see Supplemental Material S5 for the detailed statistical analyses). A clearer evening rush hour can be observed in the LSSR 2020 period, but the values are generally reduced compared to the others suggesting a substantial reduction in vehicular traffic that would be the major $\mathrm{NO}_{x}$ source. The morning rush hour in the LSSR 2019 period is quite pronounced showing the extent of traffic emissions under more typical traffic volumes that occurred in 2019. The LSSR $2020 \mathrm{NO}_{2}$ and $\mathrm{NO}_{\mathrm{x}}$ distributions are uniformly lower across the 24-hourly distributions. The CO morning rush hour peak was distinctly lower during LSSR 2020 than in any of the other 3 periods suggesting that the reduced mobility period was 


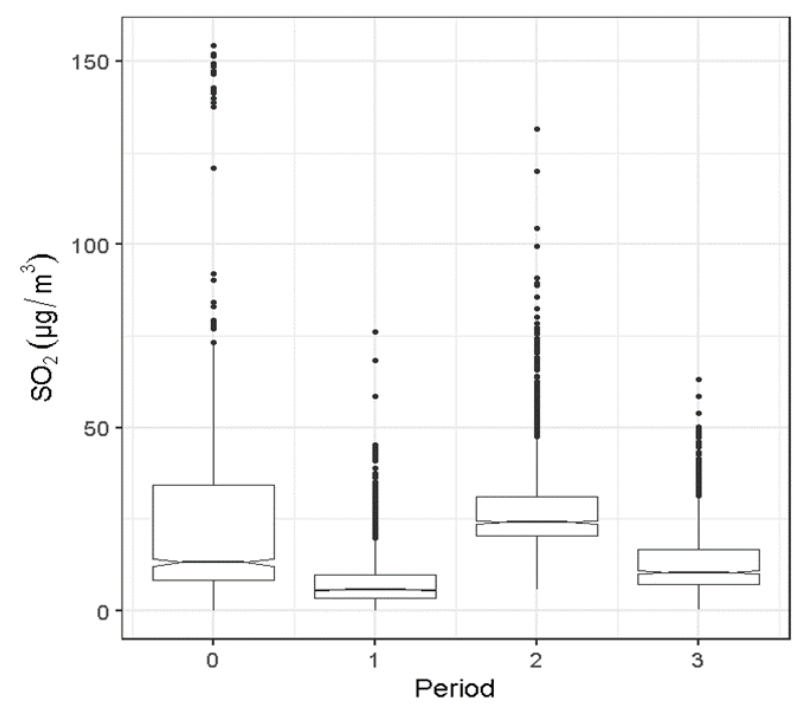

(a)

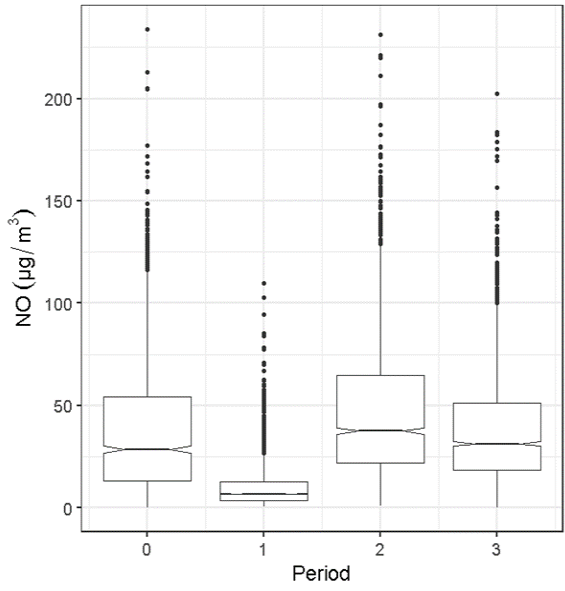

(c)

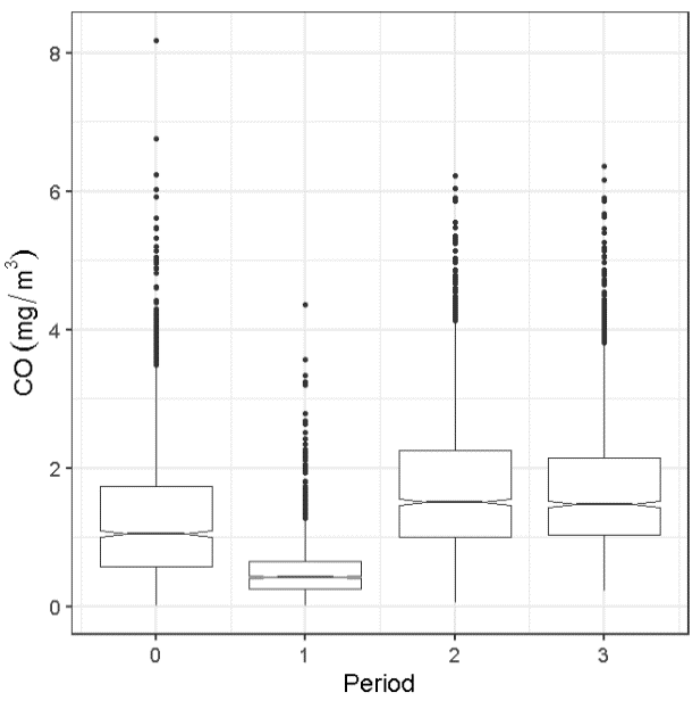

(b)

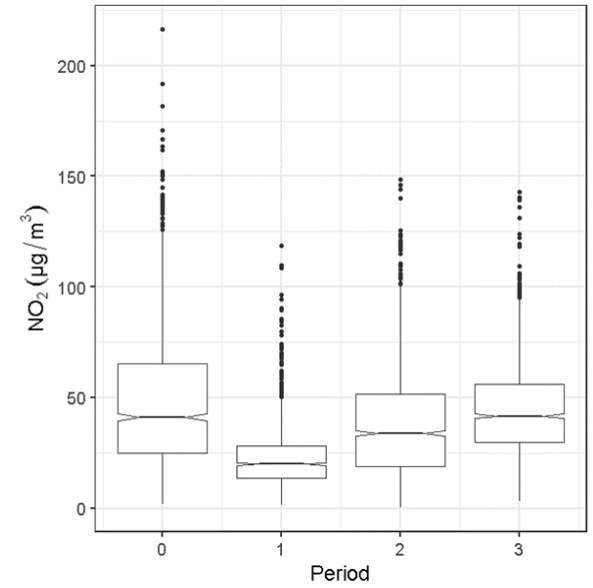

(d)

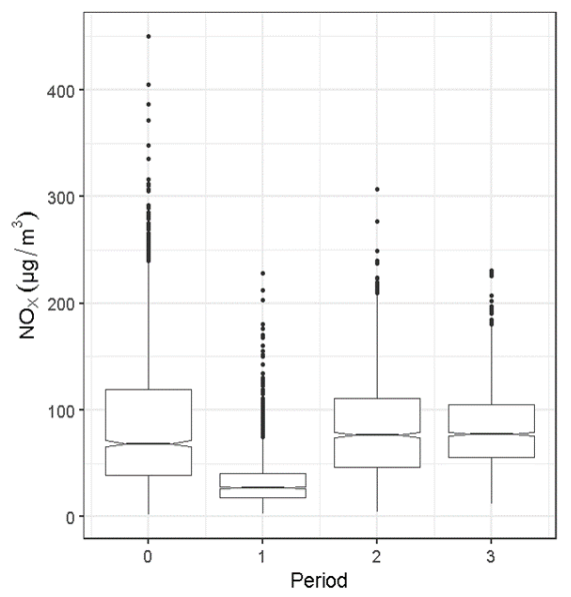

(e)

Fig. 4. Box and whisker plots of the distributions of (a) $\mathrm{SO}_{2}$, (b) $\mathrm{CO}$, (c) $\mathrm{NO}$, (d) $\mathrm{NO}_{2}$, and (e) $\mathrm{NO}_{x}$ for different periods.

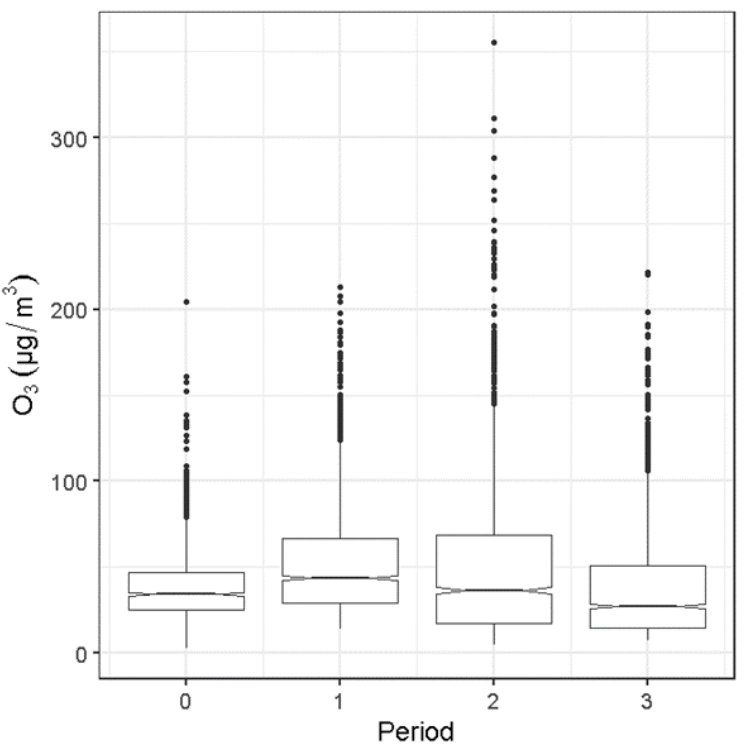

Fig. 5. Box and whisker plots of the distributions of $\mathrm{O}_{3}$ for different periods. 

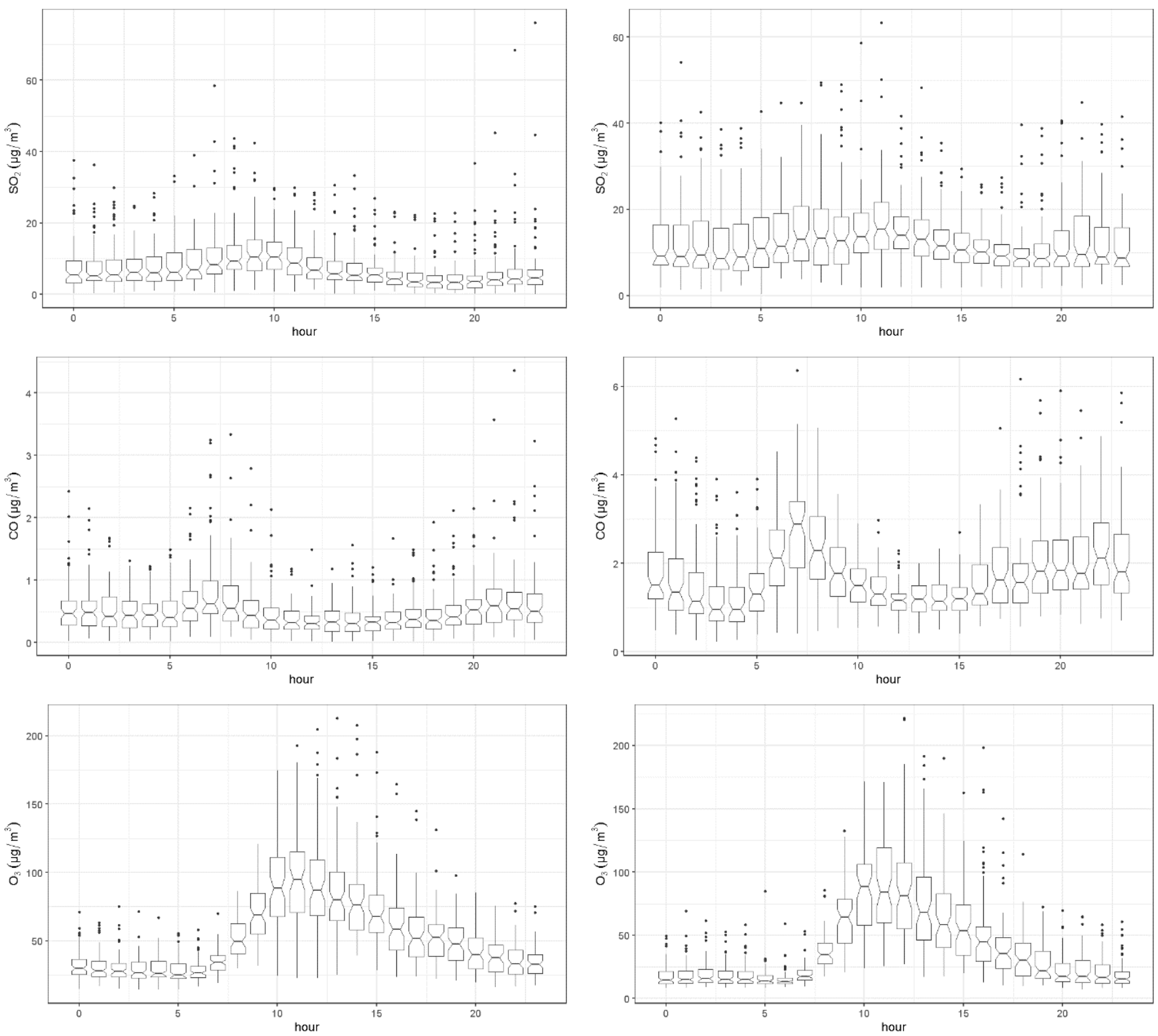

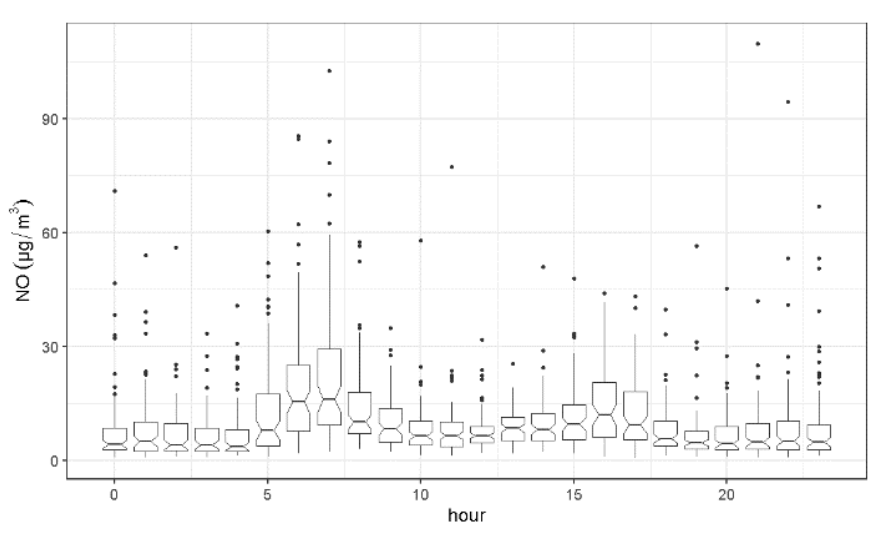

(a)

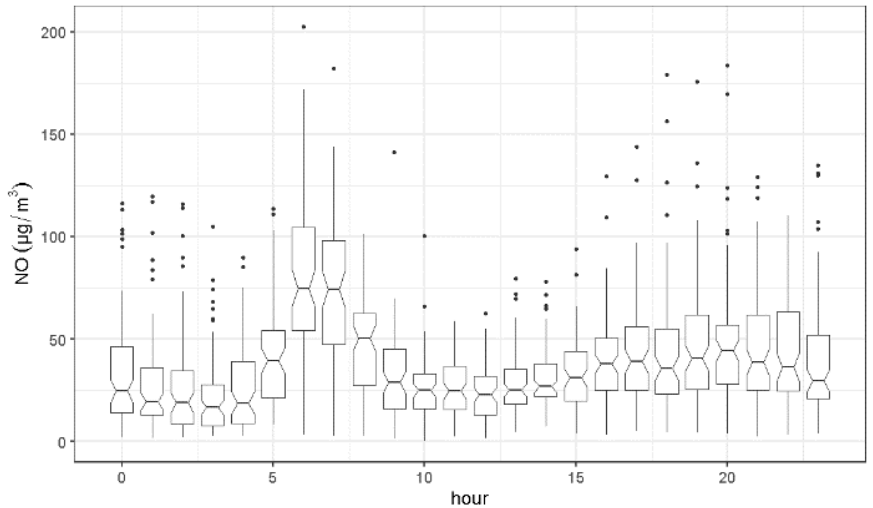

(b)

Fig. 6. Diel averages of $\mathrm{SO}_{2}, \mathrm{CO}, \mathrm{O}_{3}$ and NO (not presented in the same scale): (a) LSSR 2020, (b) LSSR 2019. 
successful in reducing the light duty traffic volume. The diel pattern of $\mathrm{SO}_{2}$ distributions in the Pre-LSSR periods showed relatively uniform hourly values over the whole day. In both LSSR periods, there were small increases from 8:00 to noon and a drop into the afternoon. Diesel fuel in Indonesia has a high sulfur content $\left(3000 \mathrm{ppm}\right.$ ) so they represent a local $\mathrm{SO}_{2}$ source. However, heavy-duty diesel trucks are restricted to overnight hours. Thus, this daytime rise seems likely to be the result of downmixing of emissions from the stacks of coal-fired power plants and oil refineries in West Java (Santoso et al., 2020). These results strongly suggest that the restricted mobility rules reduced motor vehicle traffic and some industrial activities resulting in decreased concentrations of $\mathrm{CO}, \mathrm{SO}_{2}$, and $\mathrm{NO}_{\mathrm{x}}$. However, there were increasing $\mathrm{O}_{3}$ concentration that can be understood in terms of decreased NO titration and sufficient reactive hydrocarbon concentrations to support ozone formation.

\section{2 $\mathrm{PM}_{2.5-10}$ and $\mathrm{PM}_{2.5}$ Mass and Multi-elemental Compositions}

This section presents the results of our long-term PM and composition monitoring to investigate the impact of LSSR on PM air quality in Jakarta (Santoso et al., 2020). Both coarse and fine PM monitoring results are presented and discussed separately.

\subsubsection{Coarse PM $\left(\mathrm{PM}_{2.5-10}\right)$}

We compared the period average (derived from daily average concentrations) of $\mathrm{PM}_{2.5-10}$ and compositions between pre-LSSR and LSSR period and the results are presented in Table 3 and Fig. S3. The average PM2.5-10 concentrations during the LSSR 2020, pre-LSSR 2020 and LSSR 2019 periods were $11.38 \mu \mathrm{g} \mathrm{m}^{-3}, 22.16 \mu \mathrm{g} \mathrm{m}^{-3}$, and $28.05 \mu \mathrm{g} \mathrm{m}^{-3}$, respectively. Compared to the other periods, the implementation of LSSR in 2020 reduced the concentration of $\mathrm{PM}_{2.5-10}$, as well as reduced the concentrations of its constituents. Crustal elements such as $\mathrm{Al}, \mathrm{Si}, \mathrm{Ca}$, and Fe had a dominant contribution to $\mathrm{PM}_{2.5-10}$ (Santoso et al., 2020). The concentrations of the crustal elements decreased by more than $50 \%$. There was also a substantial decrease in sulfur (particulate sulfate) compared to both the LSSR 2019 and pre-LSSR2020 periods, indicating a decrease in traffic intensity. The elements of $\mathrm{K}, \mathrm{Zn}$, and $\mathrm{Pb}$ are key indicators of anthropogenic activity and also showed decreased by more than $40 \%$ compared to the same period in 2019. During the LSSR period, there were restrictions on both commercial and social activities, so it was expected that there would be emissions reductions from street cooking, construction, and other commercial activities.

Table 3. Period average of mass and black carbon concentrations (in $\mu \mathrm{g} \mathrm{m}^{-3}$ ) and multi-elemental concentrations (in $\mathrm{ng} \mathrm{m}^{-3}$ ) of $\mathrm{PM}_{2.5-10}$ at Jakarta for different periods.

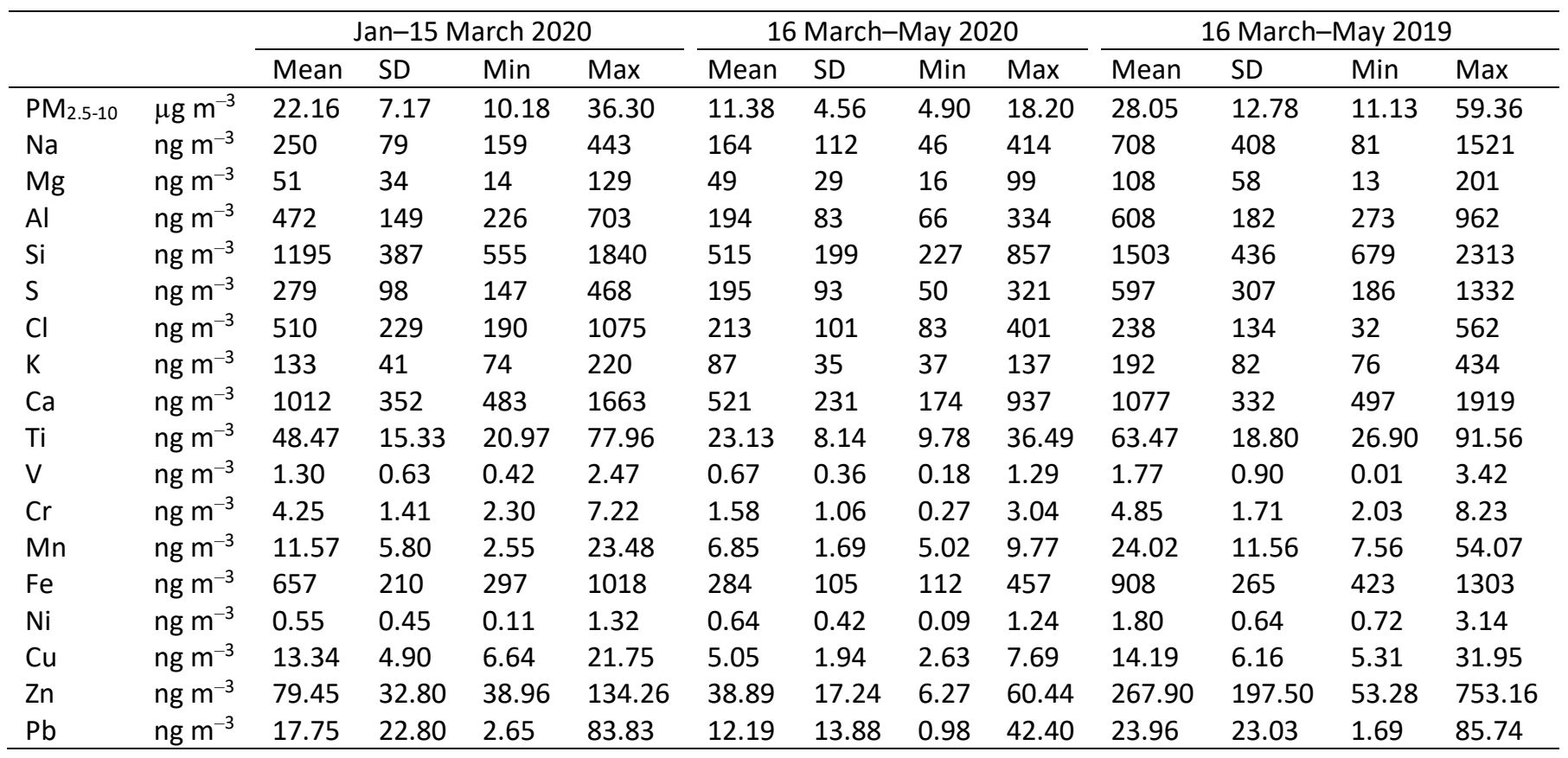


(a)

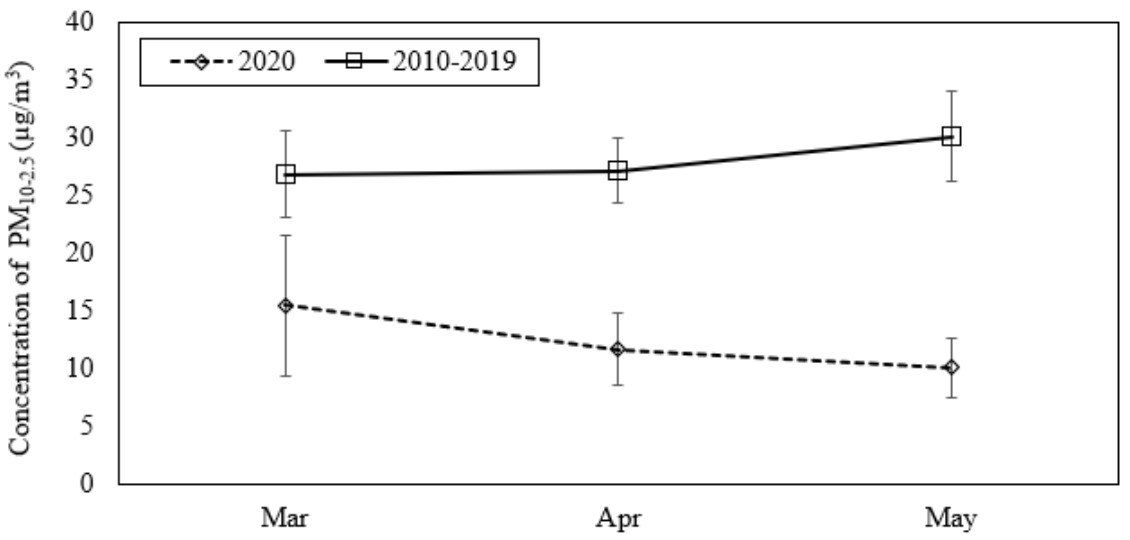

(b)

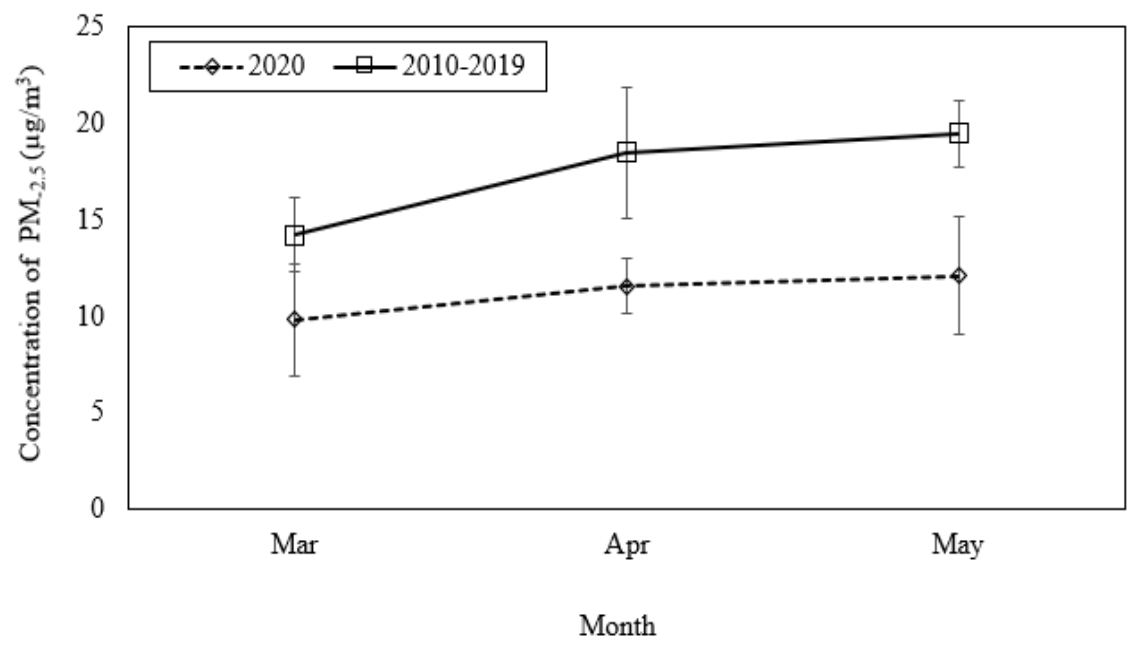

Fig. 7. Comparison of monthly average (a) $\mathrm{PM}_{2.5-10}$ and (b) $\mathrm{PM}_{2.5}$ concentration between 2020 and 2010-2019.

Monthly PM2.5-10 concentrations during the implementation of the LSSR 2020 (March-May 2020) were compared to the long-term monthly averages from 2010-2019 (Santoso et al., 2020) for the same months. The results are presented in Fig. 7(a). The monthly averages of PM2.5-10 during the LSSR period were lower than the long-term averages. For example, the March concentration was only $10 \mu \mathrm{g} \mathrm{m}^{-3}$ while the long-term average value was $27 \mu \mathrm{g} \mathrm{m}^{-3}$. Similar results were seen for April and May where the long-term average concentrations were more than double of the 2020 measurements confirming the effect of the LSSR on coarse PM at this site in Jakarta.

\subsubsection{Fine PM $\left(\mathrm{PM}_{2.5}\right)$}

Period averages of $\mathrm{PM}_{2.5}$ and elements were compared for pre-LSSR and LSSR periods and the results are presented in Table 4 and Fig. S3. In addition, measurement of BC was also reported as an indicator of diesel traffic. There was a clear reduction in $\mathrm{PM}_{2.5}$ concentrations from the preLSSR $2020\left(14.19 \mu \mathrm{g} \mathrm{m}^{-3}\right)$ to the LSSR 2020 period $\left(10.45 \mu \mathrm{g} \mathrm{m}^{-3}\right)$ and compared to LSSR 2019 $\left(18.76 \mu \mathrm{g} \mathrm{m}^{-3}\right) . \mathrm{PM}_{2.5}$ is mainly derived from anthropogenic sources such as fossil fuel combustion. Thus, it is likely related primarily to the reductions in the traffic activity and to a lesser extent on reductions of other combustion sources. Compared to 2019, the average S concentration during LSSR 2020 decreased by more than $50 \%$ from $1333 \mathrm{ng} \mathrm{m}^{-3}$ to $543 \mathrm{ng} \mathrm{m}^{-3}$, but the concentration did not change compared to pre-LSSR 2020. Average $S$ concentration was similar between the LSSR 2020 period and the pre-2020. The value was also lower than in the LSSR 2019 period. BC concentrations declined by more than $30 \%$ due to the reduction of on-road transport. Compared to the 2019 period, there was a decrease in the concentration of the elements $\mathrm{Pb}, \mathrm{Zn}, \mathrm{Cu}, \mathrm{Fe}$ in the LSSR 2020 period by more than 50\%, while K and Ca declined by $\sim 30 \%$. The decrease in 
Table 4. Period average of mass concentrations (in $\mu \mathrm{g} \mathrm{m}^{-3}$ ) and multi-elemental concentration (in $\mathrm{ng} \mathrm{m}^{-3}$ ) of $\mathrm{PM}_{2.5}$ at Jakarta from September 2019 to May 2020.

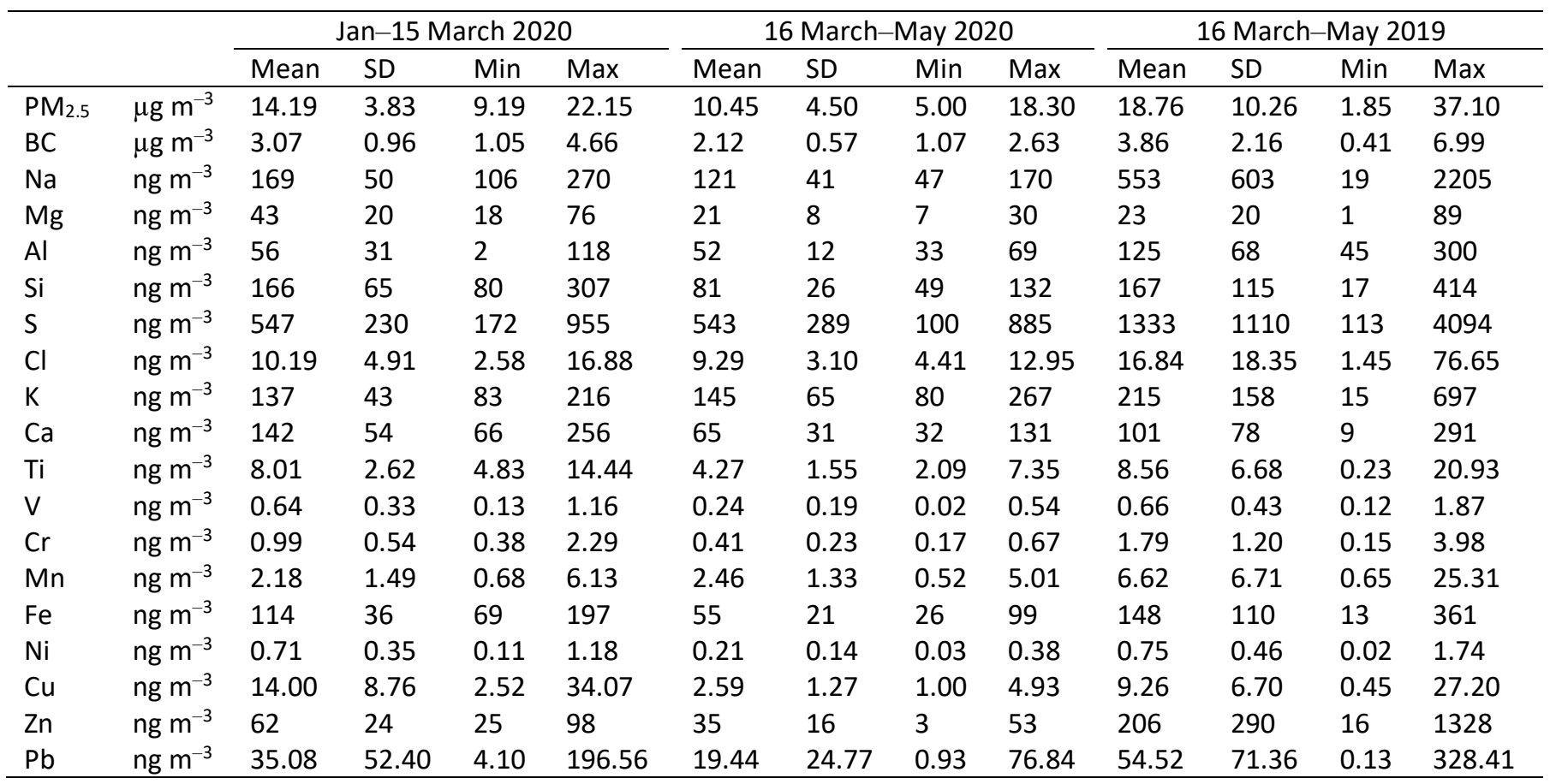

elemental concentrations during the LSSR 2020 period was a result of the reduced anthropogenic activities during the LSSR implementation in Jakarta.

Long term monthly average $\mathrm{PM}_{2.5}$ concentrations were calculated for March, April and May during the period of 2010-2019. We then compared the values with those calculated for the year of 2020 when the LSSR was implemented and the result is presented in Fig. 7(b). Typical reduction of concentration during the LSSR were also clearly seen. In all months, the $\mathrm{PM}_{2.5}$ concentration reduction ranged from $31 \%$ to $38 \%$. This reduction was comparable to the values reported in the other studies conducted in India and China (Chen et al., 2020; Mahato et al., 2020).

\subsection{Aerosol Optical Depth Observation}

Fig. 8. shows the monthly average AOD during the pre-LSSR and LSSR periods. Overall, the monthly average AOD observed during the LSSR period were higher than those measured from October-December 2019, but lower than in January and February 2020. The period average values showed a clear AOD reduction during the LSSR period compared to the Pre-LSSR (normal).

AOD measurement estimates the aerosol burden in a column of atmosphere therefore it is not only affected by the ground emission but also the upper air meteorology. The average values were affected by the number of daily data available hence data completeness is important. The AOD data were correlated with the ground PM measurements at the same site. The data provided an indication that the improvement of PM air quality during the LSSR period was also captured by the ground based AOD observations.

The AOD was compared with the $\mathrm{PM}_{2.5}$ concentrations obtained from the two sites presented above (filter-based (daily) and continuous monitoring) for the period of Oct 2019-May 2020 (See Fig. S4). Comparison of more than 25 data pairs for the second site showed relatively good correlation between AOD and our $\mathrm{PM}_{2.5}$ data (showed by coefficient of determination value, $\mathrm{r}^{2}$ of 0.596). A comparison for more than 100 data pairs between AOD and PM2.5 measured at EPA's automatic monitoring station also showed a moderate correlation with $r^{2}=0.453$. Therefore, there was a consistent PM reduction as shown by these data.

The MODIS Terra AOD (for both land and ocean) were retrieved for periods: a) March-May 2018, b) March-May 2019, c) Nov 2019-Feb 2020, and d) March-May 2020 (LSSR implementation). The spatial distribution of the MODIS Terra AOD for the selected periods are presented in Fig. 9. 


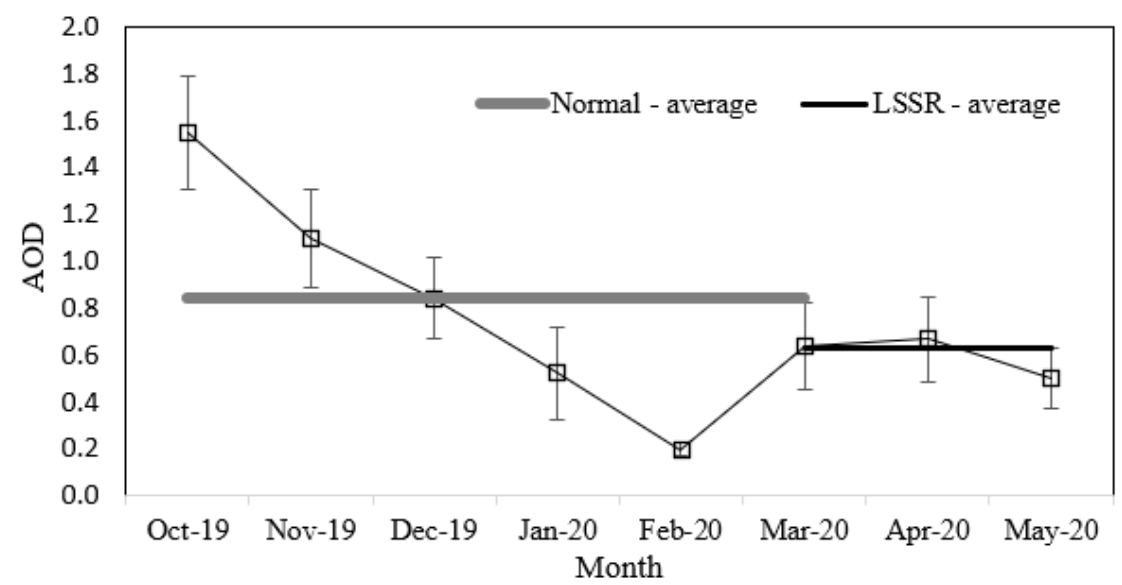

Fig. 8. Monthly and period average AOD constructed during October 2019-May 2020.

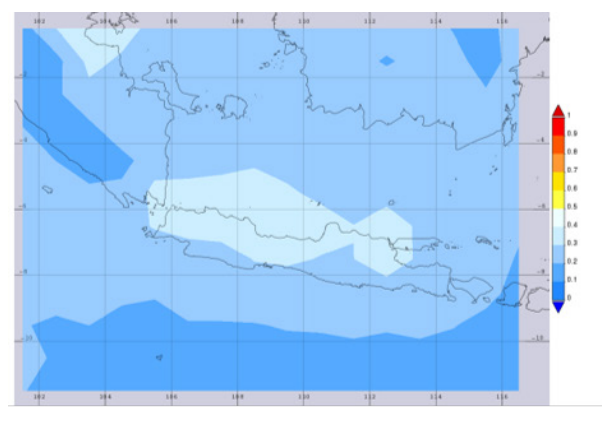

a) March - May 2018

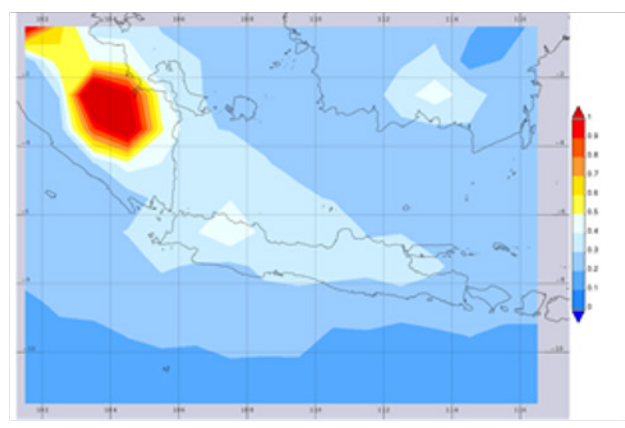

c) November $2019-$
February 2020

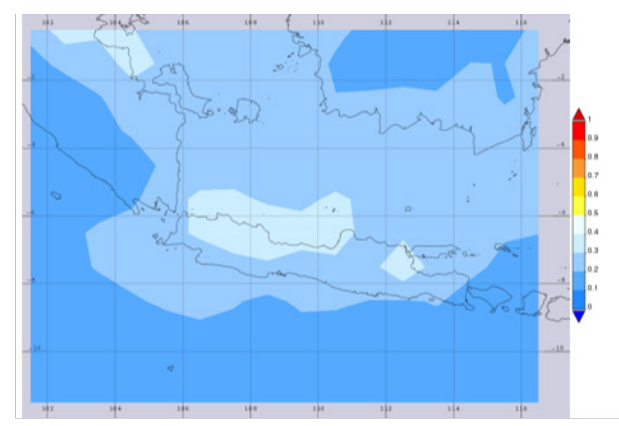

b) March - May 2019

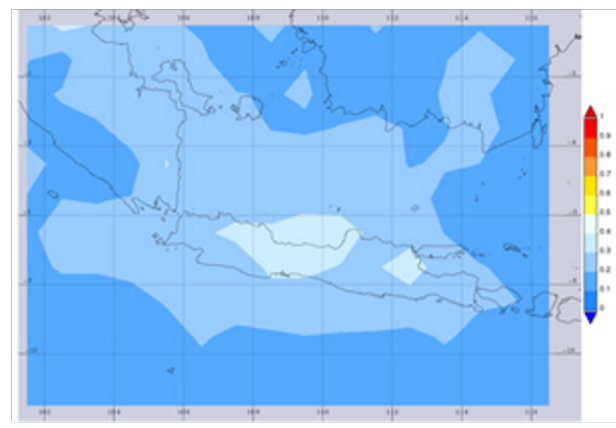

d) March - May 2020

Fig. 9. Terra MODIS AOD for different periods.

The observed AOD value over the Jakarta area for the period of March-May 2020 were consistently lower than the values observed in other 3 periods. The values ranged from 0.3 to 0.4 during the LSSR period while in other periods consistently ranged from 0.4 to 0.5 .

These findings supported the results from the ground AOD observations. Larger scale observation by satellite observed similar AOD reduction patterns especially above the Jakarta area. An exceptional situation was seen in Fig. 9(c) since in the September to February period, a forest fire hotspot was seen over the provinces of Riau and Jambi (Sumatera Island). However, it would not affect Jakarta's air quality due to the southwest monsoon synoptic winds. The reduction was also seen for other areas especially in the western part of Java Island. 
Various air quality observations combining ground-based and satellite derived data were utilized to investigate the impact of the LSSR 2020 on urban air quality in Jakarta, Indonesia. Continuous monitoring data from the AQMS installed in Central Jakarta showed reductions in $\mathrm{PM}_{2.5}, \mathrm{NO}_{2}, \mathrm{CO}$, and $\mathrm{SO}_{2}$ concentrations during the LSSR period as compared to the period before (normal). However, ozone increased in the LSSR 2020 period. Our long-term PM monitoring at another site located in the southern part of the city showed consistent substantial reductions of coarse and fine PM as well as major elements during the LSSR period. The findings were enhanced by the ground-based and MODIS Terra AOD observations which showed exceptional lower AOD values during the period where traffic and other anthropogenic activities were reduced. While the results indicated that the government's program was rather successful as seen from the air quality monitoring data, the situation maybe different in other areas where the data do not exist. It is suggested that this study should be followed up by the epidemiological research to investigate the potential short-term health benefits.

\section{ACKNOWLEDGMENTS}

The authors acknowledge the National Nuclear Energy Agency (BATAN) for the financial support throughout this work. The authors also gratefully acknowledge to all the staffs in Radiometry Analytical Techniques group in Center for Applied Nuclear Science and Technology BATAN and Jakarta Provincial EPA for their technical assistance. Besides that, the authors also thank the International Atomic Energy Agency for financial support through a research project no. TCINS7007. AERONET and BMKG are highly acknowledged for providing the AOD data for this study. Muhayatun Santoso, Philip K Hopke, and Didin Agustian Permadi are the main contributors to this article.

\section{DISCLAIMER}

Reference to any companies or specific commercial products does not constitute an endorsement by the authors, the Center for Applied Nuclear Science and Technology BATAN, the Jakarta Provincial EPA, or the International Atomic Energy Agency

\section{SUPPLEMENTARY MATERIAL}

Supplementary material for this article can be found in the online version at https://doi. org/10.4209/aaqr.200645

\section{REFERENCES}

Abdullah, S., Mansor, A.A., Liyana, N.N., Napi, M. (2020). Air quality status during 2020 Malaysia Movement Control Order (MCO) due to 2019 novel coronavirus (2019-nCoV) pandemic. Sci. Total Environ. 729, 139022. https://doi.org/10.1016/j.scitotenv.2020.139022

Alemayehu, Y.A., Asfaw, A.L., Terfie, T.A. (2020). Exposure to urban particulate matter and its association with human health risks. Environ. Sci. Pollut. Res. 27, 27491-27506. https://doi.org/ 10.1007/s11356-020-09132-1

Begum, B.A., Biswas, S.K., Hopke, P.K. (2011). Key issues in controlling air pollutants in Dhaka, Bangladesh. Atmos. Environ. 45, 7705-7713. https://doi.org/10.1016/j.atmosenv.2010.10.022

Biswas, S.K., Tarafdar, S.A., Islam, A., Khaliquzzaman, M., Tervahattu, H., Kupiainen, K. (2003). Impact of unleaded gasoline introduction on the concentration of lead in the air of Dhaka, Bangladesh. J. Air Waste Manage. Assoc. 53, 1355-1362. https://doi.org/10.1080/10473289. 2003.10466299

Blanco-Becerra, L.C., Gáfaro-Rojas, A.I., Rojas-Roa, N.Y. (2015). Influence of precipitation 
scavenging on the $\mathrm{PM}_{2.5} / \mathrm{PM}_{10}$ ratio at the Kennedy locality of Bogotá, Colombia. Revista Facultad de Ingeniería, Universidad de Antioquia 76, 58-65. https://doi.org/10.17533/udea.redin.n76a07

Bonferroni, C.E. (1936). Teoria statistica delle classi e calcolo delle probabilità. Pubblicazioni del $\mathrm{R}$ Istituto Superiore di Scienze Economiche e Commerciali di Firenze 8, 3-62. https://doi.org/ 10.4135/9781412961288.n455 (In Italian).

Brauer, M., Freedman, G., Frostad, J., Van Donkelaar, A., Martin, R.V., Dentener, F., van Dingenen, R., Estep, K., Amini, H., Apte, J.S., Balakrishnan, K., Barregard, L., Broday, D., Feigin, V., Ghosh, S., Hopke, P.K., Knibbs, L.D., Kokubo, Y., Liu, Y., et al. (2016). Ambient air pollution exposure estimation for the global burden of disease 2013. Environ. Sci. Technol. 50, 79-88. https://doi.org/10.1021/acs.est.5b03709

Brunekreef, B., Holgate, S.T. (2002). Air pollution and health. Lancet 360, 1233-1242. https://doi.org/10.1016/S0140-6736(02)11274-8

Burnett, R., Chen, H., Szyszkowicz, M., Fann, N., Hubbell, B., Pope, C.A., Apte, J.S., Brauer, M., Cohen, A., Weichenthal, S., Coggins, J., Di, Q., Brunekreef, B., Frostad, J., Lim, S.S., Kan, H., Walker, K.D., Thurston, G.D., Hayes, R.B., Lim, C.C., et al. (2018). Global estimates of mortality associated with long-term exposure to outdoor fine particulate matter. PNAS 115, 9592-9597. https://doi.org/10.1073/pnas.1803222115

Caraka, R.E., Lee, Y., Kurniawan, R., Herliansyah, R., Kaban, P.A., Nasution, B.I., Gio, P.U., Chen, R.C., Toharudin, T., Pardamean, B. (2020). Impact of COVID-19 large scale restriction on environment and economy in Indonesia, Global J. Environ. Sci. Manage. 6, 65-84. https://doi.org/10.22034/GJESM.2019.06.SI.07

Chen, Q.X., Huang, C.L., Yuan, Y., Tan, H.P. (2020). Influence of COVID-19 event on air quality and their association in mainland China. Aerosol Air Qual. Res. 20, 1541-1551. https://doi.org/10. 4209/aaqr.2020.05.0224

Chen, T.M., Kuschner, W.G., Gokhale, J., Shofer, S. (2007). Outdoor air pollution: Nitrogen dioxide, sulfur dioxide, and carbon monoxide health effects. Am. J. Med. Sci. 333, 249-256. https://doi.org/10.1097/maj.0b013e31803b900f

Commins, B.T., Waller, R.E. (1967). Observations from a ten-year-study of pollution at a site in the city of London. Atmos. Environ. 1, 49-68. https://doi.org/10.1016/0004-6981(67)90108-4

Coulson, J., Ellison, J.K. (1963). A calibration of the filter-paper method of estimation of smoke. Br. J. Appl. Phys. 14, 899-903. https://doi.org/10.1088/0508-3443/14/12/317

Diffusion System Manufacture, Ltd. (2012). Manual of EEL 43M Smoke Stain Reflectometer.

Guo, Y.R., Cao, Q.D., Hong, Z.S., Tan, Y.Y., Chen, S.D., Jin, H.J., Tan, K.S., Wang, D.Y., Yan, Y. (2020). The origin, transmission and clinical therapies on coronavirus disease 2019 (COVID-19) outbreak - An update on the status. Mil. Med. Res. 7, 11. https://doi.org/10.1186/s40779-02000240-0

Holben, B.N., Eck, T.F., Slutsker, I., Tanré, D., Buis, J.P., Setzer, A., Vermote, E., Reagan, J.A., Kaufman, Y.J., Nakajima, T., Lavenu, F., Jankowiak, I., Smirnov, A. (1998). AERONET-A federated instrument network and data archive for aerosol characterization. Remote Sens. Environ. 66, 1-16. https://doi.org/10.1016/S0034-4257(98)00031-5

Hopke, P.K., Xie, Y., Raunemaa, T., Biegalski, S., Landsberger, S., Maenhaut, W., Artaxo, P.C.D. (1997). Characterization of the gent stacked filter unit $\mathrm{PM}_{10}$ sampler. Aerosol Sci. Technol. 27, 726-735. https://doi.org/10.1080/02786829708965507

Hsiao, T.C., Chuang, H.C., Griffith, S.M., Chen, S.J., Young, L.H. (2020). COVID-19: An aerosol's point of view from expiration to transmission to viral-mechanism. Aerosol Air Qual. Res. 20, 905-910. https://doi.org/10.4209/aaqr.2020.04.0154

Huang, X, Ding, A., Gao, J., Zheng, B., Zhou, D., Qi, X., Tang, R., Wang, J., Ren, C., Nie, Q., Chi, X., Xu, Z., Chen, L., Li, Y., Che, F., Pang, N., Wang, H., Tong, D., Qin, W., Cheng, W., Liu, W., et al. (2021) Enhanced secondary pollution offset reduction of primary emissions during COVID-19 lockdown in China. Nat. Sci. Rev. 8, nwaa137. https://doi.org/10.1093/nsr/nwaa137

Kruskal, W.H., Wallis, W.A. (1952). Use of ranks in one-criterion variance analysis. J. Am. Stat. Assoc. 47, 583-621. https://doi.org/10.1080/01621459.1952.10483441

Landsberger, S., Creatchman, M. (1999). Elemental Analysis of Airborne Particles (1st ed.). Amsterdam. Gordon and Breach Science Publisher, Netherland. https://books.google.co.id/bo oks/about/Elemental_Analysis_of_Airborne_Particles.html?id=2-Vvc-wszOQC\&printsec=front cover\&source=kp_read_button\&redir_esc $=y \# v=$ onepage $\& q \& f=f a l s e$ 
Lestiani, D.D., Santoso, M., Hidayat, A. (2008). Characteristic of black carbon in fine particulate matter at Bandung and Lembang sites 2004-2005. Indonesian J. Nuclear Sci. Technol. Vol. IX, No. 2, Agustus 2008 (in Indonesian).

Liu, J., Zheng, X., Tong, Q., Tong, Q., Li, W., Wang, B., Sutter, K., Trilling, M., Lu, M., Dittmer, U., Yang, D. (2020). Overlapping and discrete aspects of the pathology and pathogenesis of the emerging human pathogenic coronaviruses SARS-CoV, MERS-CoV, and 2019-nCoV. J. Med. Virol. 92, 491-494. https://doi.org/10.1002/jmv.25709

Mahato, S., Pal, S., Ghosh, K.G. (2020). Effect of lockdown amid COVID-19 pandemic on air quality of the megacity Delhi, India. Sci. Total Environ. 730, 139086. https://doi.org/10.1016/j.scitoten v.2020.139086

McGuinn, L.A., Schneider, A., McGarrah, R.W., Ward-Caviness, C., Neas, L.M., Di, Q., Schwartz, J., Hauser, E.R., Kraus, W.E., Cascio, W.E., Diaz-Sanchez, D., Devlin, R.B. (2019). Association of long-term $\mathrm{PM}_{2.5}$ exposure with traditional and novel lipid measures related to cardiovascular disease risk. Environ. Int. 122, 193-200. https://doi.org/10.1016/j.envint.2018.11.001

Mood, A.M. (1954). On the Asymptotic efficiency of certain nonparametric two-sample tests. Ann. Math. Statist. 25, 514-522. https://doi.org/10.1214/aoms/1177728719

Muhamad, S., Long, X., Salman, M. (2020). COVID-19 pandemic and environmental pollution: A blessing in disguise? Sci. Total Environ. 728, 138820. https://doi.org/10.1016/j.scitotenv.2020. 138820

Murray, C.J.L., Aravkin, A.Y., Zheng, P., Abbafati, C., Abbas, K.M., Abbasi-Kangevari, M., Abd-Allah, F., Abdelalim, A., Abdollahi, M., Abdollahpour, I., Abegaz, K.H., Abolhassani, H., Aboyans, V., Abreu, L.G., Abrigo, M.R.M., Abualhasan, A., Abu-Raddad, L.J., Abushouk, A.I., Adabi, M., Adekanmbi, V., et al. (2020). Global burden of 87 risk factors in 204 countries and territories, 1990-2019: A systematic analysis for the Global Burden of Disease Study 2019. The Lancet 396, 1223-1249. https://doi.org/10.1016/S0140-6736(20)30752-2

Permadi, D.A., Kim Oanh, N.T. (2008). Episodic ozone air quality in Jakarta in relation to meteorological conditions. Atmos. Environ. 42, 6806-6815. https://doi.org/10.1016/j.atmose nv.2008.05.014

Qiu, Z., Ali, M.A., Nichol, J.E., Bilal, M., Tiwari, P., Habtemicheal, B.A., Almazroui, M., Mondal, S.K., Mazhar, U., Wang, Y., Sarker, S., Mustafa, F., Rahman, M.A. (2021) Spatiotemporal investigations of multi-sensor air pollution data over Bangladesh during COVID-19 lockdown. Remote Sens. 13, 877. https://doi.org/10.3390/rs13050877

Rahman, A., Luo, C., Khan, MHR., Ke, J., Thilakanayaka, V., Kumar, S. (2019). Influence of atmospheric $\mathrm{PM}_{2.5}, \mathrm{PM}_{10}, \mathrm{O}_{3}, \mathrm{CO}, \mathrm{NO}_{2}, \mathrm{SO}_{2}$, and meteorological factors on the concentration of airborne pollen in Guangzhou, China. Atmos. Environ. 212, 290-304. https://doi.org/10.10 16/j.atmosenv.2019.05.049

Rahman, H.O., Barus, L.S. (2019). Impact of Car-Free day on air pollution and its multivarious advantages in Sudirman-Thamrin Street, Jakarta. Int. J. GEOMATE 17, 167-172. https://doi.org/ 10.21660/2019.62.8286

Santoso, M, Lestiani, D.D., Mukhtar, R., Hamonangan, E., Syafrul, H., Markwitz, A., Hopke, P.K. (2011). Preliminary study of the sources of ambient air pollution in Serpong, Indonesia. Atmos. Pollut. Res. 2, 190-196. https://doi.org/10.5094/APR.2011.024

Santoso, M., Lestiani, D.D., Markwitz, A. (2013). Characterization of airborne particulate matter collected at Jakarta roadside of an arterial road. J. Radioanal. Nucl. Ch. 297, 165-169. https://doi.org/10.1007/s10967-012-2350-5

Santoso, M., Lestiani, D.D. (2014). X ray Fluorescence in Member States Application of ED XRF in supporting national program of air quality. IAEA Newsletter.

Santoso, M., Lestiani, D.D., Damastuti, E., Kurniawati, S., Kusmartini, I., Dwi Atmodjo, D.P., Sari, D.K., Muhtarom, T., Permadi, D.A., Hopke, P.K. (2020). Long term characteristics of atmospheric particulate matter and compositions in Jakarta, Indonesia. Atmos. Pollut. Res. 11, 2215-2225. https://doi.org/10.1016/j.apr.2020.09.006

Seinfeld, J.H., Pandis, S.N. (2016). Atmospheric Chemistry and Physics: From Air Pollution to Climate Change, Third Ed. John Wiley \& Sons, Hoboken, NJ.

Seneviratne, M.C.S., Waduge, V.A., Hadagiripathira, L., Sanjeewani, S., Attanayake, T., Jayaratne, N., Hopke, P.K. (2011). Characterization and source apportionment of particulate pollution in Colombo, Sri Lanka. Atmos. Pollut. Res. 2, 207-212. https://doi.org/10.5094/APR.2011.026 
Sharma, P., Khare, M. (1999). Application of intervention analysis for assessing the effectiveness of CO pollution control legislation in India. Transport. Res. Transport Environ. 4, 427-432. https://doi.org/10.1016/S1361-9209(99)00015-2

Shereen, M.A., Khan, S., Kazmi, A., Bashir, N., Siddique, R. (2020). COVID-19 infection: Origin, transmission, and characteristics of human coronaviruses. J. Adv. Res. 24, 91-98. https://doi.org/10.1016/j.jare.2020.03.005

Suhadi, D.R., Awang, M., Hassan, M.N., Abdullah, R., Muda, A.H. (2020). Review of photochemical smog pollution in Jakarta Metropolitan, Indonesia. Am. J. Environ. Sci. 1, 110-118. https://doi.org/10.3844/ajessp.2005.110.118

U.S. Environmental Protection Agency (U.S. EPA) (2019). Integrated Science Assessment (ISA) for Particulate Matter, Report No. EPA/600/R-19/188, Center for Public Health and Environmental Assessment Office of Research and Development U.S. Environmental Protection Agency Research Triangle Park, NC, December 2019.

Wang, Q., Su, M. (2020). A preliminary assessment of the impact of COVID-19 on environment A case study of China. Sci. Total Environ. 728, 138915. https://doi.org/10.1016/j.scitotenv.202 0.138915

World Health Organization (WHO) (2005). WHO Air Quality Guidelines for Particulate Matter, Ozone, Nitrogen Dioxide and Sulfur Dioxide-Global Update 2005. WHO, Copenhagen.

World Health Organization (WHO) (2006). WHO Air Quality Guidelines for Particulate Matter, Ozone, Nitrogen Dioxide and Sulfur Dioxide-Global Update 2005-Summary of Risk Assessment, 2006. WHO, Geneva. http://apps.who.int/iris/bitstream/handle/10665/69477/WHO_SDE_PH E_OEH_06.02_eng.pdf?sequence=1

World Health Organization (WHO) (2020). WHO Coronavirus disease (COVID-19) Dashboard. https://covid19. who (accessed 5 September 2020).

Zhou, Y., Yue, Y., Bai, Y., Zhang, L. (2020). Effects of rainfall on $\mathrm{PM}_{2.5}$ and $\mathrm{PM}_{10}$ in the middle reaches of the Yangtze River. Adv. Meteorol. 2020, 2398146. https://doi.org/10.1155/2020/23 98146

Zhu, Z., Lian X., Su, X., Wu, W., Marraro, G.A., Zeng, Y. (2020). From SARS and MERS to COVID-19: A brief summary and comparison of severe acute respiratory infections caused by three highly pathogenic human coronaviruses. Respir. Res. 21, 224. https://doi.org/10.1186/s12931-02001479-w 